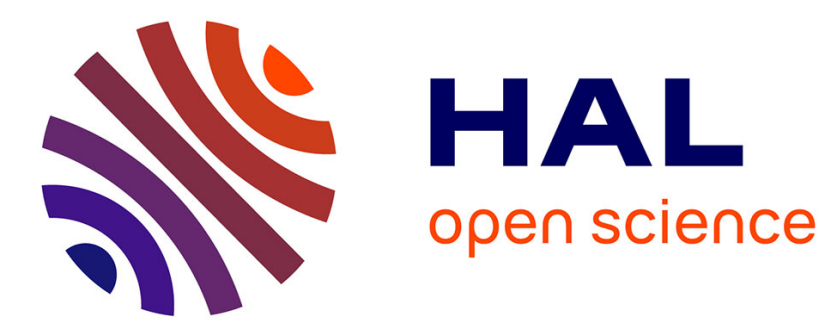

\title{
A model of oxygen adsorption at liquid copper surfaces
} P. Wynblatt, S. Curiotto, D. Chatain

\section{To cite this version:}

P. Wynblatt, S. Curiotto, D. Chatain. A model of oxygen adsorption at liquid copper surfaces. Surface Science: A Journal Devoted to the Physics and Chemistry of Interfaces, 2010, 604 (17-18), pp.13691376. 10.1016/j.susc.2010.04.015 . hal-00523852

\section{HAL Id: hal-00523852 \\ https://hal.science/hal-00523852}

Submitted on 17 Apr 2018

HAL is a multi-disciplinary open access archive for the deposit and dissemination of scientific research documents, whether they are published or not. The documents may come from teaching and research institutions in France or abroad, or from public or private research centers.
L'archive ouverte pluridisciplinaire HAL, est destinée au dépôt et à la diffusion de documents scientifiques de niveau recherche, publiés ou non, émanant des établissements d'enseignement et de recherche français ou étrangers, des laboratoires publics ou privés. 


\title{
A model of oxygen adsorption at liquid copper surfaces
}

\author{
P. Wynblatt ${ }^{1}$, S. Curiotto ${ }^{2}$, D. Chatain ${ }^{2 \#}$ \\ ${ }^{1}$ Department of Materials Science and Engineering, Carnegie Mellon University, Pittsburgh \\ PA 15206, USA; pw01@andrew.cmu.edu \\ ${ }^{2}$ CNRS, Aix-Marseille University, CINAM-UPR3118, campus de Luminy, case 913, 13288 \\ Marseille, France; curiotto@cinam.univ-mrs.fr; chatain@cinam.univ-mrs.fr
}

\#corresponding author: phone +33 (0)660302890; fax +33 (0)491418916

\begin{abstract}
A model of $\mathrm{O}$-adsorption at liquid metal surfaces has been constructed, using liquid $\mathrm{Cu}$ as an example. The modeling approach used is similar to the regular solution scheme previously used successfully for modeling the adsorption/segregation behavior of metal alloys, in that the internal energy of the system is evaluated by nearest neighbor bond energies. In the model, the adsorption of oxygen in the near-surface region is allowed to occur at both surface and sub-surface sites. The model predicts a variety of possible adsorption characteristics, including the possibility of first order adsorption transitions which involve the formation of a 2-dimensional surface oxide, and different sequences for the occupancy of surface and subsurface adsorption sites. In particular, by fitting the model to the experimental dependence of $\mathrm{Cu}$ surface energy on O-partial pressure, it is possible to conclude that O-adsorption in that case most likely occurs by the occupancy of sub-surface sites.
\end{abstract}

Keywords: surface energy; equilibrium thermodynamics; surface segregation; liquid copperoxygen surfaces 


\section{INTRODUCTION}

Metals generally interact strongly with oxygen. The nature of the interaction depends on the partial pressure of oxygen $\left(\mathrm{pO}_{2}\right)$ in the atmosphere to which the metal is exposed. When the oxygen partial pressure corresponding to the limit of solubility of oxygen in the metal is exceeded, a bulk oxide becomes thermodynamically stable, whereas below that pressure, oxygen is generally adsorbed at the metal surface. In some cases, it is also possible for a two-dimensional (2-d) "surface oxide" to form within the adsorption regime, i.e. at an oxygen partial pressure lower than that corresponding to bulk oxide formation [1-4].

One important consequence of adsorption is that it decreases surface energy, thereby affecting all capillarity-related behavior $[5,6]$. Other types of behavior may also be modified. For example, it has recently been suggested that the formation of 2-d surface oxides may improve the catalytic performance of copper when it is used to catalyze the oxidation of gas phase species [4].

There has been considerable interest in modeling adsorption/segregation phenomena at metal surfaces. Previous work has generally used one of three approaches: computer simulations which make use of semi-empirical interaction potentials [7,8], first principles calculations [9], and analytical thermodynamic models [10-13]. The first two approaches have tended to address adsorption energies, and the manner in which surface structure changes with adsorption. On the other hand, the thermodynamic approach has been based on a simplified description of the surface structure and has focused on estimates of the dependence of adsorption on the chemical potential of the adsorbing species, and on the resulting changes in surface energy.

In this paper, we make use of the thermodynamic approach to investigate oxygen adsorption at the surface of liquid copper. In metal alloy systems, this type of modeling uses the heat of mixing to quantify the interaction between the alloy components, and the surface energy of the pure components to quantify the surface energy of the (segregated) alloy [12, $14,15]$. In the present case of adsorption from the gas phase, several technical difficulties need to be resolved. (i) The sites occupied by oxygen in copper need to be defined; (ii) the best method to formulate realistic copper-oxygen interactions is not obvious; and (iii) a means must be found to define the contribution to the surface energy of an adsorbed "oxygen entity".

A great deal of work has been performed on the location of adsorbed oxygen on copper surfaces of different orientations, using ultra-high vacuum (UHV) experimental approaches such as low energy electron diffraction, scanning tunneling microcopy, Auger 
electron spectroscopy, etc. As will be described in more detail below, the density and degree of close packing of a liquid surface is quite similar to that of the (111) surface of a face centered cubic (FCC) metal [16-19]. Thus, some indications on the behavior of adsorbed oxygen on a liquid copper surface could in principle be obtained from studies of oxygen adsorption on $\mathrm{Cu}(111)$. However, in UHV work, oxygen is adsorbed on the surface by exposing samples to a known flux of oxygen, until the desired oxygen coverage is obtained. Thus, no relation is obtained between oxygen adsorption and oxygen chemical potential.

In contrast to the surface science methodology, measurements aimed at the determination of surface energy of liquid copper have been performed under a well-defined oxygen chemical potential. In these experiments the liquid copper surface is exposed to a mixture of gases that produce a given $\mathrm{pO}_{2}$ [20-23], and the surface energy is measured by the sessile drop technique. However, these measurements suffer from the disadvantage that $\mathrm{O}-$ adsorption is not measured directly.

Several previous attempts have been made at modeling O-adsorption at liquid metal surfaces by the thermodynamic approach, $[6,24,25]$. These studies have made use of the Gibbs adsorption isotherm, which may be expressed as follows:

$$
\gamma_{M}=\gamma_{M}^{0}-\Gamma_{M} \mu_{M}-\Gamma_{O} \mu_{O}
$$

where $\gamma_{M}$ is the surface energy, $\gamma_{M}^{0}$ is the surface energy of the pure metal $\mathrm{M}, \Gamma_{\mathrm{j}}$ is the adsorption of the species $\mathrm{j}(\mathrm{O}$ and $\mathrm{M})$, and $\mu_{\mathrm{j}}$, the chemical potential of the jth species. Ricci et al. [24] and Eustathopoulos et al. [25] have used a concept developed by Wagner [26] in which oxygen is described as an oxide cluster dissolved in a sea of metal. This so-called "coordination cluster theory" provides a good description of the bulk thermodynamics of oxygen dissolved in metals and alloys [27-29]. Saiz et al. [6] have followed the approach of Belton [30], in which the Langmuir adsorption isotherm is combined with the Gibbs adsorption isotherm. That approach uses experimental data on the relationship between surface energy and oxygen potential to evaluate adsorption, and cannot therefore be used to predict adsorption behavior independently of adsorption-related experimental information.

The model presented in this paper aims to link the macroscopic approach of previous authors $[6,24,25]$ to a mean-field atomic description of the surface thermodynamics of oxygen at the surface of liquid copper. It is similar to the Belton approach in that we combine Gibbsian adsorption with a Langmuir-like model. However, unlike the classical Langmuir approach, our model does not limit adsorption to a single type of adsorption site, and we have avoided the assumption that the adsorption coefficient is independent of coverage. In 
addition, while the data used as input to the model is derived from experimental measurements of surface energies of the relevant pure components, none of the input data is either directly or indirectly related to O-adsorption.

\section{MODEL}

\subsection{General Structure}

The approach used here is similar to the regular solution scheme previously used successfully for modeling the adsorption (or interfacial segregation) behavior of metal alloys $[10-12,14]$. In that approach, the energy due to interactions between the two species $(\mathrm{Cu}$ and $\mathrm{O})$ is approximated by nearest neighbor bond energies and the entropy is taken to be that of an ideal solution. Such a method is reasonable for the description of systems such as $\mathrm{Cu}-\mathrm{O}$, where the interactions are predominantly covalent, but would not be appropriate, for example, in $\mathrm{Mg}-\mathrm{O}$, where the interactions are predominantly ionic, especially if there is a possibility for the formation of 2-d oxides at the surface.

We will consider O-adsorption to the surface of a $\mathrm{Cu}$ liquid. For convenience, we will assume that the atoms of the liquid occupy a FCC lattice. This type of approximation for liquids has often been adopted in the past $[11,13]$ and has yielded favorable comparisons with experimental results of adsorption at liquid surfaces. In addition, such an assumption is not unreasonable, because the coordination in liquid metals that are close-packed in the solid state is $\sim 11$ [31], and therefore not very different from that in their crystalline form. Furthermore, the arrangement of $\mathrm{Cu}$-atoms at the pure liquid surface will be taken to correspond to the structure of a FCC (111) surface, as it has been shown both experimentally $[18,19]$ and by computer modeling $[16,17]$ that liquid metal surfaces are more ordered than the bulk liquid over regions a few atom diameters in thickness, and that these ordered regions are also more densely packed than the adjacent bulk liquid. In general, this surface ordering is expected to prevail only in the vicinity of the melting point. However, measurements of liquid surface ordering in $\mathrm{Ga}$ [19] have shown that detectable ordering can persist to temperatures of up to $150 \mathrm{~K}$ above the melting temperature. In the present study we will confine application of the model to a temperature of $1365 \mathrm{~K}$, where most of the relevant surface energy measurements have been made. This temperature is only $7 \mathrm{~K}$ above the melting point of $\mathrm{Cu}$.

As the oxygen potential in equilibrium with bulk liquid $\mathrm{Cu}$ is increased, the concentration of oxygen dissolved in $\mathrm{Cu}$ also increases. When the oxygen potential reaches the value corresponding to the oxygen solubility limit, the $\mathrm{Cu}_{2} \mathrm{O}$ phase forms. Depending on 
temperature, $\mathrm{Cu}_{2} \mathrm{O}$ can be either liquid or solid. We shall focus here on the temperature domain where bulk $\mathrm{Cu}_{2} \mathrm{O}$ is solid. In solid $\mathrm{Cu}_{2} \mathrm{O}, \mathrm{Cu}$-atoms occupy the sites of a FCC lattice, and the O-atoms occupy 2 of the 8 tetrahedral holes of the $\mathrm{Cu}$ structure, as shown schematically in Fig. 1 (space group: Pn3m, lattice constant: $0.4267 \mathrm{~nm}$ [32]). The O-sites in $\mathrm{Cu}_{2} \mathrm{O}$ have also been found to be the preferred O-adsorption sites at the $\mathrm{Cu}(111)$ surface by first principles calculations [4]. For the purposes of the current model, we assume that Oatoms dissolved in $\mathrm{Cu}$ also occupy the same type of $\mathrm{O}$-sites as in $\mathrm{Cu}_{2} \mathrm{O}$.

We use the structure of the $\mathrm{Cu}_{2} \mathrm{O}(111)$ surface of as a guide for the structure of the $\mathrm{Cu}$ surface containing adsorbed $\mathrm{O}$. The $\mathrm{Cu}_{2} \mathrm{O}(111)$ surface can be viewed as consisting of a FCC stacking of (111) Cu-planes with O-sites lying both above and below these planes. The two types of O-sites will be referred to as upper and lower sites, as illustrated schematically in Figs. 1 and 2. It is also useful to number the $\mathrm{Cu}$ layers with a superscript $\mathrm{i}, \mathrm{Cu}^{(\mathrm{i})}$, where $\mathrm{i}=1$ refers to the surface $\mathrm{Cu}$ layer. The upper O-sites associated with $\mathrm{Cu}^{(1)}$ will be labeled $\mathrm{O} 1$. These lack one of their four $\mathrm{Cu}$-neighbors and four of their eight nearest O-neighbors. The lower O-sites associated with $\mathrm{Cu}^{(1)}$ are labeled $\mathrm{O} 2$. These have their full complement of $\mathrm{Cu}$ neighbors but only seven of their eight O-neighbors. We consider that segregation of oxygen at the $\mathrm{Cu}$-surface occurs by populating $\mathrm{O} 1$ and $\mathrm{O} 2$ sites adjacent to $\mathrm{Cu}^{(1)}$. O-sites associated with planes $\mathrm{Cu}^{(\mathrm{i})}$, having $\mathrm{i}>1$, are taken to have the bulk O-site fraction. Since O-atoms dissolved in $\mathrm{Cu}$ as well as $\mathrm{O}$-atoms in $\mathrm{Cu}_{2} \mathrm{O}$ are assumed to occupy their own sublattice, $\mathrm{O}$ segregation occurs by populating the near surface O-sublattice and does not require any redistribution of $\mathrm{Cu}$ atoms on the $\mathrm{Cu}$-sublattice.

The internal energy of the segregated system is calculated by means of a nearest neighbor bond model. We consider the following types of bonds. The Cu-neighbors of an Oatom are considered "special" in the sense that there may be some electronic interaction between them and the adjacent $\mathrm{O}$-atom. Thus, these $\mathrm{Cu}$-atoms are labeled $\mathrm{Cu}^{\prime}$, and the energy of $\mathrm{Cu}^{\prime}-\mathrm{O}$ bonds is labeled $\varepsilon_{\mathrm{Cu}} \mathrm{O}$. Similarly, the energy of bonds connecting two special $\mathrm{Cu}^{\prime}-$

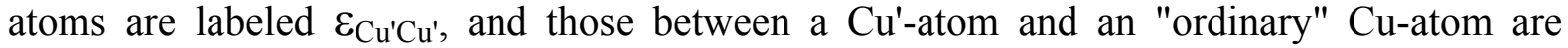
labeled $\varepsilon_{\mathrm{Cu}} \mathrm{Cu}$. Finally, the bonds between nearest neighbor O-atoms are labeled $\varepsilon_{\mathrm{OO}}$, and those between a pair of ordinary $\mathrm{Cu}$ atoms are labeled $\varepsilon_{\mathrm{CuCu}}$. Note that a $\mathrm{Cu}$ atom in the segregated layer can have up to two O-neighbors. However, $\mathrm{Cu}$-atoms have been labeled $\mathrm{Cu}$ ', whether they have one or two O-neighbors. This simplification has been made in order to 
avoid proliferation of bond energy types (such as $\varepsilon_{\mathrm{Cu}} \mathrm{Cu}, \varepsilon_{\mathrm{Cu}} \mathrm{Cu}^{\prime}$, etc.) because, as will be seen later, there is only limited data available to define the bond energies.

Entropy contributions associated with the distribution of $\mathrm{O}$-atoms on $\mathrm{O}$-sites, is computed in the ideal solution approximation, and the internal energy due to bonds is computed assuming a random distribution of $\mathrm{O}$-atoms on $\mathrm{O}$-sublattice sites.

The equilibrium surface composition is obtained by minimizing the surface energy w.r.t. the fractions of occupied $\mathrm{O} 1$ and $\mathrm{O} 2$ sites. The advantage of this approach is that it naturally yields the surface energy of the system as a function of $\mathrm{O}$-adsorption.

\subsection{Equilibrium surface composition}

The number of O-sites in each set of upper and lower O-sites associated with a given $\mathrm{Cu}$ plane is defined as $\mathrm{N}_{\mathrm{O}}$ in units of moles per unit surface area. The number of $\mathrm{Cu}$-sites/area in each $\mathrm{Cu}$ plane is defined as $\mathrm{N}_{\mathrm{Cu}}$ in the same units. Thus, from the structure of Fig. 1, we have:

$$
4 \mathrm{~N}_{\mathrm{O}}=\mathrm{N}_{\mathrm{Cu}}
$$

The fractions of occupied $\mathrm{O} 1$ and $\mathrm{O} 2$ sites (associated with $\mathrm{Cu}^{(1)}$ ) are $\mathrm{X}_{\mathrm{O} 1}$ and $\mathrm{X}_{\mathrm{O} 2}$, respectively, and the fraction of occupied $\mathrm{O}$-sites associated with all other $\mathrm{Cu}$ planes is $\mathrm{X}_{\mathrm{Ob}}$, corresponding to the fractional occupancy of $\mathrm{O}$ in a bulk layer. As noted above, $\mathrm{Cu}$ species may be identified as $\mathrm{Cu}$ or $\mathrm{Cu}^{\prime}$. It is convenient to define the fractions of $\mathrm{Cu}-\mathrm{Cu}, \mathrm{Cu}-\mathrm{Cu}$ and $\mathrm{Cu}^{\prime}-\mathrm{Cu}^{\prime}$ bonds in each $\mathrm{Cu}$ layer as $\mathrm{f}^{(\mathrm{i})} \mathrm{CuCu}, \mathrm{f}^{(\mathrm{i})} \mathrm{Cu}^{\prime} \mathrm{Cu}$ and $\mathrm{f}^{(\mathrm{i})}{ }_{\mathrm{Cu}}^{\prime} \mathrm{Cu}^{\prime}$, respectively, where the superscript $\mathrm{i}$ indicates the plane $\mathrm{Cu}^{(\mathrm{i})}$. O-atoms occupying $\mathrm{O} 2$ sites of the $\mathrm{Cu}^{(1)}$ plane have $\mathrm{Cu}$ neighbors in the $\mathrm{Cu}^{(2)}$ plane, and thus modify the fractions of $\mathrm{Cu}$ and $\mathrm{Cu}^{\prime}$ atoms in that plane. As a result, the interactions between $\mathrm{Cu}$-atoms occupying the $\mathrm{Cu}^{(1)}$ and $\mathrm{Cu}^{(2)}$ planes, as well as the $\mathrm{Cu}^{(2)}$ and $\mathrm{Cu}^{(3)}$ planes, are also modified. To address this issue, we also define the fractions of the three types of bonds that connect $\mathrm{Cu}$-atoms in adjacent $\mathrm{Cu}^{(\mathrm{i})}$ and $\mathrm{Cu}^{(\mathrm{j})}$ planes as $\mathrm{f}^{(\mathrm{i}-\mathrm{j})} \mathrm{hk}\left(\mathrm{h}, \mathrm{k}=\mathrm{Cu}, \mathrm{Cu}^{\prime}\right)$. Finally, it should be mentioned that $\mathrm{O}$-atoms have first neighbor $\mathrm{O}$ sites which lie as far as three O-layers away, as shown in Fig. 1. Thus, for example, O-atoms in the $\mathrm{O} 2$ layer have $\mathrm{O}$ neighbors which lie in the upper $\mathrm{O}$-sites of both $\mathrm{Cu}^{(2)}$ and $\mathrm{Cu}^{(3)}$ planes.

We express the surface energy as the surface excess grand potential:

$$
\gamma=\mathrm{e}^{\mathrm{s}}-\mathrm{Ts}^{\mathrm{s}}-\sum_{\mathrm{j}} \Gamma_{\mathrm{j}} \mu_{\mathrm{j}}
$$

where $\gamma$ is the surface energy, $\mathrm{e}^{\mathrm{S}}$ and $\mathrm{s}^{\mathrm{S}}$ are the surface excess internal energy and entropy per unit area, respectively, and $\Gamma_{\mathrm{j}}$ and $\mu_{\mathrm{j}}$ are the adsorption and chemical potential of the $\mathrm{jth}$ component $(j=\mathrm{Cu}, \mathrm{O})$. Since there is no surface excess of $\mathrm{Cu}$ in the present problem, i.e. the 
number of $\mathrm{Cu}$-atoms per unit area remains the same in the near-surface layers as in the bulk layers, $\Gamma_{\mathrm{Cu}}$ vanishes, and the sum of Eq. 2 reduces to $\Gamma_{\mathrm{O}} \mu_{\mathrm{O}}$.

Let us now consider a system consisting of $3 \mathrm{Cu}$ surface planes $\left(\mathrm{Cu}^{(\mathrm{i})}, \mathrm{i}=1,2,3\right)$ attached to $\mathrm{M}$ bulk-like $\mathrm{Cu}$ layers. We write the surface excess terms of Eq. 2 by subtracting the free energy of $(\mathrm{M}+3)$ bulk layers from that of the system under consideration. This leads to identical cancellation of the free energies of the $M$ bulk layers, leaving the energy of the three surface layers, less the free energy of three bulk layers. Thus, $\gamma$ may be expressed as:

$$
\begin{aligned}
& \gamma=\mathrm{N}_{\mathrm{O}}\left[3 \mathrm{X}_{\mathrm{O} 1} \varepsilon_{\mathrm{Cu} \mathrm{O}^{\prime}}+4 \mathrm{X}_{\mathrm{O} 2} \varepsilon_{\mathrm{Cu}} \mathrm{O}+3 \mathrm{X}_{\mathrm{O} 1} \mathrm{X}_{\mathrm{O} 2} \varepsilon_{\mathrm{OO}}+0.5 \mathrm{X}_{\mathrm{O} 1} \mathrm{X}_{\mathrm{Ob}} \varepsilon_{\mathrm{OO}}+2 \mathrm{X}_{\mathrm{O} 2} \mathrm{X}_{\mathrm{Ob}} \varepsilon_{\mathrm{OO}}\right] \\
& +3 \mathrm{~N}_{\mathrm{Cu}}\left[\mathrm{f}^{(1)} \mathrm{CuCu} \varepsilon_{\mathrm{CuCu}}+\mathrm{f}^{(1)} \mathrm{Cu}^{\prime} \mathrm{Cu} \varepsilon_{\mathrm{Cu}}{ }^{\prime} \mathrm{Cu}+\mathrm{f}^{(1)} \mathrm{Cu}^{\prime} \mathrm{Cu}^{\prime} \varepsilon_{\mathrm{Cu}^{\prime} \mathrm{Cu}}\right] \\
& +3 \mathrm{~N}_{\mathrm{Cu}}\left[\mathrm{f}^{(1-2)}{ }_{\mathrm{CuCu}} \varepsilon_{\mathrm{CuCu}}+\mathrm{f}^{(1-2)} \mathrm{Cu}^{\prime} \mathrm{Cu} \varepsilon_{\mathrm{Cu}} \mathrm{Cu}+\mathrm{f}^{(1-2)} \mathrm{Cu}^{\prime} \mathrm{Cu}^{\prime} \varepsilon_{\mathrm{Cu}^{\prime} \mathrm{Cu}}\right] \\
& +\mathrm{N}_{\mathrm{O}} \mathrm{RT}\left[\mathrm{X}_{\mathrm{O} 1} \ln \left(\mathrm{X}_{\mathrm{O} 1}\right)+\left(1-\mathrm{X}_{\mathrm{O} 1}\right) \ln \left(1-\mathrm{X}_{\mathrm{O} 1}\right)+\mathrm{X}_{\mathrm{O} 2} \ln \left(\mathrm{X}_{\mathrm{O} 2}\right)+\left(1-\mathrm{X}_{\mathrm{O} 2}\right) \ln \left(1-\mathrm{X}_{\mathrm{O} 2}\right)\right] \\
& +\mathrm{N}_{\mathrm{O}}\left[8 \mathrm{X}_{\mathrm{Ob}} \varepsilon_{\mathrm{Cu}} \mathrm{O}+1.5 \mathrm{X}_{\mathrm{Ob}} \mathrm{X}_{\mathrm{O} 2} \varepsilon_{\mathrm{OO}}+0.5 \mathrm{X}_{\mathrm{Ob}} \mathrm{X}_{\mathrm{O} 1} \varepsilon_{\mathrm{OO}}+5.5 \mathrm{X}_{\mathrm{Ob}}^{2} \varepsilon_{\mathrm{OO}}\right] \\
& +3 \mathrm{~N}_{\mathrm{Cu}}\left[\mathrm{f}^{(2)}{ }_{\mathrm{CuCu}} \varepsilon_{\mathrm{CuCu}}+\mathrm{f}^{(2)} \mathrm{Cu}^{\prime} \mathrm{Cu} \varepsilon_{\mathrm{Cu}} \mathrm{Cu}+\mathrm{f}^{(2)} \mathrm{Cu}^{\prime} \mathrm{Cu}^{\prime} \varepsilon_{\mathrm{Cu}} \mathrm{Cu}^{\prime}\right] \\
& +3 \mathrm{~N}_{\mathrm{Cu}}\left[\mathrm{f}^{(2-3)} \mathrm{CuCu}_{\mathrm{Cu}} \varepsilon_{\mathrm{CuCu}}+\mathrm{f}^{(2-3)} \mathrm{Cu}^{\prime} \mathrm{Cu} \varepsilon_{\mathrm{Cu}} \mathrm{Cu}+\mathrm{f}^{(2-3)} \mathrm{Cu}^{\prime} \mathrm{Cu}^{\prime} \varepsilon_{\mathrm{Cu}^{\prime} \mathrm{Cu}}\right] \\
& +2 \mathrm{~N}_{\mathrm{O}} \mathrm{RT}\left[\mathrm{X}_{\mathrm{Ob}} \ln \left(\mathrm{X}_{\mathrm{Ob}}\right)+\left(1-\mathrm{X}_{\mathrm{Ob}}\right) \ln \left(1-\mathrm{X}_{\mathrm{Ob}}\right)\right] \\
& +\mathrm{N}_{\mathrm{O}}\left[8 \mathrm{X}_{\mathrm{Ob}} \varepsilon_{\mathrm{Cu}^{\prime} \mathrm{O}}+0.5 \mathrm{X}_{\mathrm{Ob}} \mathrm{X}_{\mathrm{O} 2} \varepsilon_{\mathrm{OO}}+7.5 \mathrm{X}_{\mathrm{Ob}}^{2} \varepsilon_{\mathrm{OO}}\right] \\
& +3 \mathrm{~N}_{\mathrm{Cu}}\left[\mathrm{f}^{(\mathrm{b})} \mathrm{CuCu} \varepsilon_{\mathrm{CuCu}}+\mathrm{f}^{(\mathrm{b})}{ }_{\mathrm{Cu}}^{\prime} \mathrm{Cu} \varepsilon_{\mathrm{Cu}} \mathrm{Cu}+\mathrm{f}^{(\mathrm{b})} \mathrm{Cu}^{\prime} \mathrm{Cu}^{\prime} \varepsilon_{\mathrm{Cu} u^{\prime} \mathrm{Cu}^{\prime}}\right]
\end{aligned}
$$

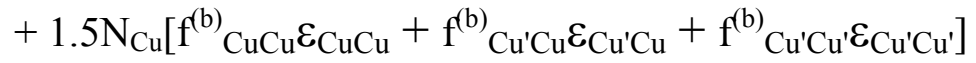

$$
\begin{aligned}
& +2 \mathrm{~N}_{\mathrm{O}} \mathrm{RT}\left[\mathrm{X}_{\mathrm{Ob}} \ln \left(\mathrm{X}_{\mathrm{Ob}}\right)+\left(1-\mathrm{X}_{\mathrm{Ob}}\right) \ln \left(1-\mathrm{X}_{\mathrm{Ob}}\right)\right] \\
& -3\left\{2 \mathrm{~N}_{\mathrm{O}} \mathrm{X}_{\mathrm{Ob}}\left[4 \mathrm{X}_{\mathrm{Ob}} \varepsilon_{\mathrm{OO}}+4 \varepsilon_{\mathrm{Cu} \mathrm{O}^{\prime}}\right]\right.
\end{aligned}
$$

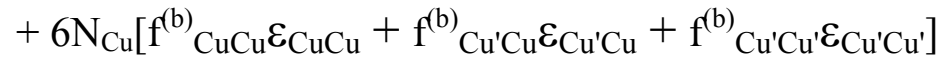

$$
\begin{aligned}
& \left.+2 \mathrm{~N}_{\mathrm{O}} \mathrm{RT}\left[\mathrm{X}_{\mathrm{Ob}} \ln \left(\mathrm{X}_{\mathrm{Ob}}\right)+\left(1-\mathrm{X}_{\mathrm{Ob}}\right) \ln \left(1-\mathrm{X}_{\mathrm{Ob}}\right)\right]\right\} \\
& -\Gamma_{\mathrm{O}} \mu_{\mathrm{O}}
\end{aligned}
$$

Here, $\mathrm{f}^{(\mathrm{b})}{ }_{\mathrm{hk}}$ is the fraction of bonds of the various types in a bulk-like layer. Note that there is no difference between in-layer bond fractions $f^{(b)}{ }_{h k}$ and interlayer bond fractions $f^{(b-b)}{ }_{h k}$. The first term in Eq. 3 accounts for the bond energies of the interactions between $\mathrm{O}$-atoms in $\mathrm{O} 1$ and $\mathrm{O} 2$ sites with other $\mathrm{O}$-atoms and with $\mathrm{Cu}$-atoms (as an example, an explanation of how these values are obtained is given in Appendix I), the second term represents the bond energies within plane $\mathrm{Cu}^{(1)}$, and the third term gives the energies of the bonds between the $\mathrm{Cu}^{(1)}$ and $\mathrm{Cu}^{(2)}$ planes. The fourth term gives the entropy of mixing of the $\mathrm{O} 1$ and $\mathrm{O} 2$ atoms 
on the O-sublattice. There is no entropy associated with mixing of $\mathrm{Cu}$ and $\mathrm{Cu}^{\prime}$ on $\mathrm{Cu}$ sublattice sites, because that distribution is determined by the distribution of the adjacent $\mathrm{O}$ atoms, and is not independent. The next four terms represent the equivalent quantities for the $\mathrm{Cu}^{(2)}$ plane. The following four terms give the same quantities for the $\mathrm{Cu}^{(3)}$ plane, except that only half of its interaction with layer $\mathrm{Cu}^{(4)}$ is included, as the other half was subtracted with the free energy of the $M$ bulk layers to obtain the surface excess free energy. The next three terms of Eq. 3 represent the free energy of the 3 bulk layers that are subtracted to yield the surface excess free energy. The last term subtracts the adsorption and chemical potential term.

The various terms $\mathrm{f}^{(\mathrm{i})} \mathrm{hk}$ and $\mathrm{f}^{(\mathrm{i}-\mathrm{j})}{ }_{\mathrm{hk}}$, are not always easy to calculate, because of the awkward geometry of the $\mathrm{Cu}_{2} \mathrm{O}$ structure. In many cases they had to be evaluated by averaging over many simulations in which O-atoms were distributed at random among the various sites. The standard deviations of the values obtained by the simulations were typically about $10 \%$ of the mean values. However, the mean values are robust, and are the only significant values needed in such a mean field model. The values obtained are summarized in Table 1, where all the bond fractions are expressed as functions of the principal composition variables: $\mathrm{X}_{\mathrm{O} 1}, \mathrm{X}_{\mathrm{O} 2}$ and $\mathrm{X}_{\mathrm{Ob}}$.

One minor inconsistency in Eq. 3 should be noted. O-atoms occupying upper O-sites of the $\mathrm{Cu}^{(2)}$ layer have one dangling $\mathrm{O}-\mathrm{O}$ bond (due to the presence of the surface), and the O-concentration of that layer should therefore strictly be considered to be variable. This has been ignored in the present model, and the fraction of occupied O-sites in that layer has been set to $\mathrm{X}_{\mathrm{Ob}}$.

We now turn to an evaluation of the last terms in Eq. 3, namely: the O-adsorption, and the $\mathrm{O}$-chemical potential. The $\mathrm{O}$-adsorption is just the surface excess number of moles of $\mathrm{O}$ per unit area, and may be written:

$$
\Gamma_{0}=N_{0}\left(X_{01}+X_{02}-2 X_{0 b}\right)
$$

The chemical potential is somewhat more involved, and requires the definition of some additional terms. Thus far, we have described the bulk composition in terms of $\mathrm{X}_{\mathrm{Ob}}$, the fraction of occupied $\mathrm{O}$-sites in the $\mathrm{O}$-sublattice associated with planes $\mathrm{Cu}^{(\mathrm{i})}(\mathrm{i}>1)$. It is convenient to redefine the bulk composition of the $\mathrm{Cu}-\mathrm{O}$ alloy in terms of the conventional atom fraction of oxygen, which we shall denote as $X_{O}^{C}$ (the superscript $C$ standing for "conventional"). The relationships between $\mathrm{X}_{\mathrm{Ob}}$ and $\mathrm{X}_{\mathrm{O}}^{\mathrm{C}}$ are: 


$$
X_{O}^{C}=\frac{X_{O b}}{2+X_{O b}} \text {, or } X_{O b}=\frac{2 X_{O}^{C}}{1-X_{O}^{C}}
$$

We also need to write an expression for the bulk free energy of the $\mathrm{Cu}-\mathrm{O}$ alloy. This can be extracted from Eq. 3 where we included terms for the free energy of three bulk $\mathrm{Cu}$ layers with their associated $\mathrm{O}$-atoms. The free energy of a single bulk layer is defined as $\mathrm{F}^{\mathrm{b}}\left(\mathrm{X}_{\mathrm{Ob}}\right)$ :

$$
\begin{aligned}
& \mathrm{F}^{\mathrm{b}}\left(\mathrm{X}_{\mathrm{Ob}}\right)=2 \mathrm{~N}_{\mathrm{O}} \mathrm{X}_{\mathrm{Ob}}\left[4 \mathrm{X}_{\mathrm{Ob}} \varepsilon_{\mathrm{OO}}+4 \varepsilon_{\mathrm{Cu}} \mathrm{O}\right] \\
& +24 \mathrm{~N}_{\mathrm{O}}\left[\mathrm{f}^{(\mathrm{b})} \mathrm{CuCu} \varepsilon_{\mathrm{CuCu}}+\mathrm{f}^{(\mathrm{b})} \mathrm{Cu}^{\prime} \mathrm{Cu} \varepsilon_{\mathrm{Cu}} \mathrm{Cu}+\mathrm{f}^{(\mathrm{b})} \mathrm{Cu}^{\prime} \mathrm{Cu}^{\prime} \varepsilon_{\mathrm{Cu}^{\prime} \mathrm{Cu}}\right] \\
& +2 \mathrm{~N}_{\mathrm{O}} \mathrm{RT}\left[\mathrm{X}_{\mathrm{Ob}} \ln \left(\mathrm{X}_{\mathrm{Ob}}\right)+\left(1-\mathrm{X}_{\mathrm{Ob}}\right) \ln \left(1-\mathrm{X}_{\mathrm{Ob}}\right)\right]
\end{aligned}
$$

where Eq. 1 has been used to eliminate $N_{C u}$. For an alloy of bulk composition $X_{O}^{C}$, the free energy of one mole of bulk solution, $F_{m}$, is given by $X_{0}^{C}$ times the bulk free energy per mole of $\mathrm{O}$ (i.e. $\mathrm{F}^{\mathrm{b}}\left(\mathrm{X}_{\mathrm{Ob}}\right)$ divided by $\left.2 \mathrm{~N}_{\mathrm{O}} \mathrm{X}_{\mathrm{Ob}}\right)$ :

$$
F_{m}=X_{O}^{C} \frac{F^{b}\left(X_{O b}\right)}{2 N_{O} X_{O b}}=\frac{F^{b}\left(X_{O b}\right)}{2 N_{O}\left(2+X_{O b}\right)}
$$

This expression is used in Appendix II to demonstrate that the O-chemical potential can be expressed as:

$$
\begin{aligned}
& \left.\mu_{\mathrm{O}}=\left[8 \mathrm{X}_{\mathrm{Ob}} \varepsilon_{\mathrm{OO}}+4 \varepsilon_{\mathrm{Cu} u^{\prime} \mathrm{O}}\right]+12 \frac{\partial \mathrm{f}_{\mathrm{CuCu}}^{(\mathrm{b})}}{\partial \mathrm{X}_{\mathrm{Ob}}} \varepsilon_{\mathrm{CuCu}}+\frac{\partial \mathrm{f}_{\mathrm{Cu}{ }^{\prime} \mathrm{Cu}}^{(\mathrm{b})}}{\partial \mathrm{X}_{\mathrm{Ob}}} \varepsilon_{\mathrm{Cu} u^{\prime} \mathrm{Cu}}+\frac{\partial \mathrm{f}_{\mathrm{Cu}^{\prime} \mathrm{Cu} u^{\prime}}^{(\mathrm{b})}}{\partial \mathrm{X}_{\mathrm{Ob}}} \varepsilon_{\mathrm{Cu}^{\prime} \mathrm{Cu}}\right] \\
& +\mathrm{RT}\left[\ln \left(\mathrm{X}_{\mathrm{Ob}} /\left(1-\mathrm{X}_{\mathrm{Ob}}\right)\right)\right]
\end{aligned}
$$

The equilibrium values of $\mathrm{X}_{\mathrm{O} 1}$ and $\mathrm{X}_{\mathrm{O} 2}$, corresponding to $\mathrm{O}$-adsorption at the $\mathrm{Cu}$ surface, are obtained by minimizing Eq. 3, together with the definitions of $\Gamma_{O}$ and $\mu_{O}$ of Eqs. 4 and 8. This yields:

$$
\begin{aligned}
& \mathrm{RT}\left[\ln \left(\mathrm{X}_{\mathrm{O} 1} /\left(1-\mathrm{X}_{\mathrm{O} 1}\right)\right)\right]+\left[3 \mathrm{X}_{\mathrm{O} 2} \varepsilon_{\mathrm{OO}}+3 \varepsilon_{\mathrm{Cu}^{\prime} \mathrm{O}}+\mathrm{X}_{\mathrm{Ob}} \varepsilon_{\mathrm{OO}}\right] \\
& +1\left\{\frac{\partial f_{\mathrm{CuCu}}^{(1)}}{\partial \mathrm{X}_{\mathrm{O} 1}} \varepsilon_{\mathrm{CuCu}}+\frac{\partial \mathrm{f}_{\mathrm{Cu}{ }^{\prime} \mathrm{Cu}}^{(1)}}{\partial \mathrm{X}_{\mathrm{O} 1}} \varepsilon_{\mathrm{Cu} u^{\prime} \mathrm{Cu}}+\frac{\partial \mathrm{f}_{\mathrm{Cu}^{\prime} \mathrm{Cu}}^{(1)}}{\partial \mathrm{X}_{\mathrm{O} 1}} \varepsilon_{\mathrm{Cu}^{\prime} \mathrm{Cu}}\right] \\
& \left.+12 \frac{\partial f_{\mathrm{CuCu}}^{(1)(2)}}{\partial \mathrm{X}_{\mathrm{O} 1}} \varepsilon_{\mathrm{CuCu}}+\frac{\partial \mathrm{f}_{\mathrm{C}}^{(1)(2)}}{\partial \mathrm{X}_{\mathrm{O} 1}} \varepsilon_{\mathrm{Cu} u^{\prime} \mathrm{Cu}}+\frac{\partial \mathrm{f}_{\mathrm{Cu}^{\prime} \mathrm{Cu} u^{\prime}}^{(1)(2)}}{\partial \mathrm{X}_{\mathrm{O} 1}} \varepsilon_{\mathrm{Cu}^{\prime} \mathrm{Cu}}\right] \\
& \left.+12 \frac{\partial \mathrm{f}_{\mathrm{CuCu}}^{(2)}}{\partial \mathrm{X}_{\mathrm{O} 1}} \varepsilon_{\mathrm{CuCu}}+\frac{\partial \mathrm{f}_{\mathrm{Cu}}^{(2)} \mathrm{Cu}}{\partial \mathrm{X}_{\mathrm{O} 1}} \varepsilon_{\mathrm{Cu}{ }^{\prime} \mathrm{Cu}}+\frac{\partial \mathrm{f}_{\mathrm{Cu}^{\prime} \mathrm{Cu}}^{(2)}}{\partial \mathrm{X}_{\mathrm{O} 1}} \varepsilon_{\mathrm{Cu}^{\prime} \mathrm{Cu}}\right] \\
& -R T\left[\ln \left(X_{O b} /\left(1-X_{O b}\right)\right)\right]-\left[8 X_{O b} \varepsilon_{O O}+4 \varepsilon_{\mathrm{Cu}^{\prime} \mathrm{O}}\right] \\
& \left.-12 \frac{\partial \mathrm{f}_{\mathrm{CuCu}}^{(\mathrm{b})}}{\partial \mathrm{X}_{\mathrm{Ob}}} \varepsilon_{\mathrm{CuCu}}+\frac{\partial \mathrm{f}_{\mathrm{Cu}}^{(\mathrm{b})}}{\partial \mathrm{X}_{\mathrm{Ob}}} \varepsilon_{\mathrm{Cu} u^{\prime} \mathrm{Cu}}+\frac{\partial \mathrm{f}_{\mathrm{Cu}^{\prime} \mathrm{Cu} u^{\prime}}^{(\mathrm{b})}}{\partial \mathrm{X}_{\mathrm{Ob}}} \varepsilon_{\mathrm{Cu}^{\prime} \mathrm{Cu}}\right]=0
\end{aligned}
$$

and 


$$
\begin{aligned}
& \mathrm{RT}\left[\ln \left(\mathrm{X}_{\mathrm{O} 2} /\left(1-\mathrm{X}_{\mathrm{O} 2}\right)\right)\right]+\left[3 \mathrm{X}_{\mathrm{O} 1} \varepsilon_{\mathrm{OO}}+4 \varepsilon_{\mathrm{Cu}^{\prime} \mathrm{O}}+4 \mathrm{X}_{\mathrm{Ob}} \varepsilon_{\mathrm{OO}}\right] \\
& \left.+12 \frac{\partial f_{\mathrm{CuCu}}^{(1)}}{\partial \mathrm{X}_{\mathrm{O} 2}} \varepsilon_{\mathrm{CuCu}}+\frac{\partial \mathrm{f}_{\mathrm{Cu} u^{\prime} \mathrm{Cu}}^{(1)}}{\partial \mathrm{X}_{\mathrm{O} 2}} \varepsilon_{\mathrm{Cu} \mathrm{Cu}^{\prime}}+\frac{\partial \mathrm{f}_{\mathrm{Cu}^{\prime} \mathrm{Cu} u^{\prime}}^{(1)}}{\partial \mathrm{X}_{\mathrm{O} 2}} \varepsilon_{\mathrm{Cu}^{\prime} \mathrm{Cu}}\right] \\
& +1\left\{\frac{\partial f_{\mathrm{CuCu}}^{(1)(2)}}{\partial \mathrm{X}_{\mathrm{O} 2}} \varepsilon_{\mathrm{CuCu}}+\frac{\partial \mathrm{f}_{\mathrm{Cu}}^{(1)(2)}}{\partial \mathrm{X}_{\mathrm{O} 2}} \varepsilon_{\mathrm{Cu} u^{\prime} \mathrm{Cu}}+\frac{\partial \mathrm{f}_{\mathrm{Cu}^{\prime} \mathrm{Cu} u^{\prime}}^{(1)(2)}}{\partial \mathrm{X}_{\mathrm{O} 2}} \varepsilon_{\mathrm{Cu}^{\prime} \mathrm{Cu} u^{\prime}}\right] \\
& \left.+12 \frac{\partial f_{\mathrm{CuCu}}^{(2)}}{\partial \mathrm{X}_{\mathrm{O} 2}} \varepsilon_{\mathrm{CuCu}}+\frac{\partial \mathrm{f}_{\mathrm{Cu} \mathrm{Cu}^{(2)}}^{(2)}}{\partial \mathrm{X}_{\mathrm{O} 2}} \varepsilon_{\mathrm{Cu} \mathrm{Cu}^{\prime} \mathrm{Cu}}+\frac{\partial \mathrm{f}_{\mathrm{Cu}^{\prime} \mathrm{Cu} \mathrm{u}^{\prime}}^{(2)}}{\partial \mathrm{X}_{\mathrm{O} 2}} \varepsilon_{\mathrm{Cu}^{\prime} \mathrm{Cu}}\right] \\
& \left.+12 \frac{\partial f_{\mathrm{CuCu}}^{(2)(3)}}{\partial \mathrm{X}_{\mathrm{O} 2}} \varepsilon_{\mathrm{CuCu}}+\frac{\partial \mathrm{f}_{\mathrm{Cu}}^{(2)(3 u}}{\partial \mathrm{X}_{\mathrm{O} 2}} \varepsilon_{\mathrm{Cu} u^{\prime} \mathrm{Cu}}+\frac{\partial \mathrm{f}_{\mathrm{Cu}^{\prime} \mathrm{Cu}}^{(2)}}{\partial \mathrm{X}_{\mathrm{O} 2}} \varepsilon_{\mathrm{Cu}^{\prime} \mathrm{Cu}}\right] \\
& -R T\left[\ln \left(X_{\mathrm{Ob}} /\left(1-X_{\mathrm{Ob}}\right)\right)\right]-\left[8 \mathrm{X}_{\mathrm{Ob}} \varepsilon_{\mathrm{OO}}+4 \varepsilon_{\mathrm{Cu^{ \prime } \mathrm { O }}}\right] \\
& \left.-12 \frac{\partial f_{\mathrm{CuCu}}^{(\mathrm{b})}}{\partial \mathrm{X}_{\mathrm{Ob}}} \varepsilon_{\mathrm{CuCu}}+\frac{\partial f_{\mathrm{Cu} u^{\prime} \mathrm{Cu}}^{(\mathrm{b})}}{\partial \mathrm{X}_{\mathrm{Ob}}} \varepsilon_{\mathrm{Cu} u^{\prime} \mathrm{Cu}}+\frac{\partial f_{\mathrm{Cu}}^{(\mathrm{b})} \mathrm{Cu}^{\prime}}{\partial \mathrm{X}_{\mathrm{Ob}}} \varepsilon_{\mathrm{Cu}^{\prime} \mathrm{Cu} u^{\prime}}\right]=0
\end{aligned}
$$

The equilibrium surface compositions are obtained by solving Eqs. 9 simultaneously for $\mathrm{X}_{\mathrm{O} 1}$ and $\mathrm{X}_{\mathrm{O} 2}$.

\subsection{Evaluation of bond energies}

We evaluate the bond energies from the surface energies of $\mathrm{Cu}$ and $\mathrm{Cu}_{2} \mathrm{O}$. Although bond energies could in principle also be evaluated from chemical reactions, such as:

$$
1 / 2 \mathrm{O}_{2}(\mathrm{~g})+2 \mathrm{Cu}(\mathrm{l})=\mathrm{Cu}_{2} \mathrm{O}(\mathrm{s}),
$$

it is preferable to perform the assessment of bond energies from surface energies, when the purpose is to evaluate surface properties.

We obtain the $\mathrm{Cu}-\mathrm{Cu}$ bond energy from the surface energy of liquid $\mathrm{Cu}$, under the assumption that the liquid surface has the same structure as the (111) surface of the solid. Close to its melting point, the surface energy of liquid $\mathrm{Cu}$ is $1.37 \mathrm{~J} / \mathrm{m}^{2}$ which is an average of the experimental values reported later in Fig. 5. Taking into account that 3 bonds per atom

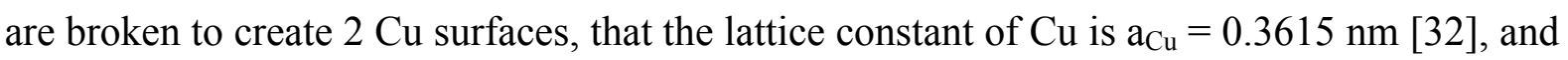
that the area occupied by a $\mathrm{Cu}$ atom at the (111) surface is $\left(\mathrm{a}_{\mathrm{Cu}}\right)^{2} \sqrt{3} / 4$, one obtains

$$
\varepsilon_{\mathrm{CuCu}}=1.37\left[\mathrm{~J} / \mathrm{m}^{2}\right]\left(\mathrm{a}_{\mathrm{Cu}}\right)^{2} /(2 \sqrt{3})\left[\mathrm{m}^{2} / \text { atom }\right]\left(6.02 \times 10^{23}[\mathrm{atom} / \mathrm{mol}]\right)=-31 \mathrm{~kJ} / \mathrm{mol} \text {. }
$$

The work required to create a (111) surface of solid $\mathrm{Cu}_{2} \mathrm{O}$ may be expressed as:

$$
-\mathrm{N}_{\mathrm{O}}^{\mathrm{Cu}_{2} \mathrm{O}}\left[2.5 \varepsilon_{\mathrm{OO}}+0.5 \varepsilon_{\mathrm{Cu}^{\prime} \mathrm{O}}+6 \varepsilon_{\mathrm{Cu}^{\prime} \mathrm{Cu}^{\prime}}\right] \text {, }
$$


where $\mathrm{N}_{\mathrm{O}}^{\mathrm{Cu}_{2} \mathrm{O}}$ is the number of oxygen moles per unit area at the $\mathrm{Cu}_{2} \mathrm{O}(111)$ surface in each of the two oxygen planes associated with the outermost $\mathrm{Cu}$ plane. The surface unit cell of $\mathrm{Cu}_{2} \mathrm{O}(111)$ shown in Fig. 2 contains one surface $\mathrm{O}$-atom, and has an area of $\mathrm{a}_{\mathrm{Cu}_{2} \mathrm{O}}^{2} \sqrt{3}$, where $\mathrm{a}_{\mathrm{Cu}_{2} \mathrm{O}}=0.4267 \mathrm{~nm}[32]$. Thus the number of moles of oxygen per unit area is $1 /\left(6.02 \times 10^{23}\right.$ [atoms $/ \mathrm{mol}] \mathrm{a}_{\mathrm{Cu}_{2} \mathrm{O}}^{2} \sqrt{3}\left[\mathrm{~m}^{2} /\right.$ atom]). No values of the surface energy of solid $\mathrm{Cu}_{2} \mathrm{O}$ are available. However, the surface energy of the liquid is reported as $0.48 \mathrm{~J} / \mathrm{m}^{2}$ [33]. We estimate the surface energy of the solid to be $15 \%$ higher than that of the liquid (typical of the relative values in pure metals) and employ the method used above to evaluate $\varepsilon_{\mathrm{CuCu}}$ to obtain:

$$
\left[2.5 \varepsilon_{\mathrm{OO}}+0.5 \varepsilon_{\mathrm{Cu}^{\prime} \mathrm{O}}+6 \varepsilon_{\mathrm{Cu}^{\prime} \mathrm{Cu}}\right]=-104.5 \mathrm{~kJ} / \mathrm{mol}
$$

As can be seen, there is not sufficient data to define all five of the bond energies in the present scheme, so that some additional conditions need to be imposed. Thus, we assume that the solution of $\mathrm{Cu}^{\prime}$ in $\mathrm{Cu}$ is ideal, i.e. that:

$$
\varepsilon_{\mathrm{Cu} u^{\prime} \mathrm{Cu}}=0.5\left(\varepsilon_{\mathrm{Cu}^{\prime} \mathrm{Cu}}+\varepsilon_{\mathrm{CuCu}}\right) \text {. }
$$

We also assume that $\varepsilon_{\mathrm{OO}}$ is positive and that $\varepsilon_{\mathrm{Cu}} \mathrm{O}$ is negative, both of which are plausible since there is likely to be some charge transfer between $\mathrm{O}$ and $\mathrm{Cu}$, as has been suggested by first principles calculations [4]. Finally, we impose one further condition, namely that the solubility of $\mathrm{O}$ in liquid $\mathrm{Cu}$ in equilibrium with $\mathrm{Cu}_{2} \mathrm{O}$ at $1365 \mathrm{~K}$ (just above the melting point of $\mathrm{Cu}$ ) is close to the experimental value of $2 \mathrm{at} \%$ [34]. This limits the possible values of the bond energies to the free choice of one bond energy, as will be discussed after the scheme to calculate the O-solubility is described.

\subsection{Calculation of the solubility of $\mathrm{O}$ in $\mathrm{Cu}$}

We determine the $\mathrm{O}$-solubility in $\mathrm{Cu}$ by applying the common tangent construction to a free energy diagram of the bulk O-solution and of the coexisting $\mathrm{Cu}_{2} \mathrm{O}$ phase. The free energy of the bulk O-solution can be extracted from the expression for the free energy per mole of solution given in Eq. 7. By substituting for $\mathrm{F}^{\mathrm{b}}\left(\mathrm{X}_{\mathrm{Ob}}\right)$ from Eq. 6, we have:

$$
\begin{aligned}
\mathrm{F}_{\mathrm{m}} & =\frac{1}{\left(2+\mathrm{X}_{\mathrm{Ob}}\right)}\left\{4 \mathrm{X}_{\mathrm{Ob}}\left[\mathrm{X}_{\mathrm{Ob}} \varepsilon_{\mathrm{OO}}+\varepsilon_{\mathrm{Cu}^{\prime} \mathrm{O}}\right]+1 \mathrm{df}_{\mathrm{CuCu}}^{(\mathrm{b})} \varepsilon_{\mathrm{CuCu}}+\mathrm{f}_{\mathrm{Cu}^{\prime} \mathrm{Cu}}^{(\mathrm{b})} \varepsilon_{\mathrm{Cu}^{\prime} \mathrm{Cu}}+\mathrm{f}_{\mathrm{Cu}^{\prime} \mathrm{Cu}^{\prime}}^{(\mathrm{b})} \varepsilon_{\mathrm{Cu}^{\prime} \mathrm{Cu}}\right] \\
& \left.+\mathrm{RT}\left[\mathrm{X}_{\mathrm{Ob}} \ln \left(\mathrm{X}_{\mathrm{Ob}}\right)+\left(1-\mathrm{X}_{\mathrm{Ob}}\right) \ln \left(1-\mathrm{X}_{\mathrm{Ob}}\right)\right]\right\}
\end{aligned}
$$

In the limit $X_{0 b} \rightarrow 1$ ( or $X_{0}^{C} \rightarrow \frac{1}{3}$ ), i.e. when all $O$-sites are filled, the bulk solution becomes identical with the compound $\mathrm{Cu}_{2} \mathrm{O}$. Thus, over the range $0 \leq \mathrm{X}_{\mathrm{Ob}} \leq 1$ (or 
$\left.\mathrm{O} \leq \mathrm{X}_{\mathrm{O}}^{\mathrm{C}} \leq \frac{1}{3}\right), \mathrm{F}_{\mathrm{m}}$ represents the molar free energy of the $\mathrm{Cu}-\mathrm{O}$ system ranging from pure $\mathrm{Cu}$ to $\mathrm{Cu}_{0.67} \mathrm{O}_{0.33}$, and can therefore be used to evaluate the solubility of the $\mathrm{Cu}-\mathrm{O}$ solution in equilibrium with $\mathrm{Cu}_{2} \mathrm{O}$ by the common tangent construction.

The constraint of fixing the $O$-solubility at $X_{0}^{C} \approx 0.0_{c}^{-}$gives rise to a linear relationship between $\varepsilon_{\mathrm{Cu}^{\prime} \mathrm{Cu}}$ and $\varepsilon_{\mathrm{OO}}$ :

$$
\varepsilon_{\mathrm{OO}}=83+3 \varepsilon_{\mathrm{Cu}^{\prime} \mathrm{Cu}}(\mathrm{kJ} / \mathrm{mol})
$$

Values of $\varepsilon_{\mathrm{Cu}^{\prime} \mathrm{Cu}^{\prime}}$ more negative than about $-23 \mathrm{~kJ} / \mathrm{mol}$ lead to complete mutual solubility of $\mathrm{Cu}_{2} \mathrm{O}$ and $\mathrm{Cu}$, and are therefore incompatible with the desired solubility limit. Thus, the possible bond energies are completely defined by the choice of a single bond energy. From now on we will describe the bond energies used in any examples by specifying $\varepsilon_{\mathrm{Cu}^{\prime} \mathrm{Cu}^{\prime}}$.

\subsection{Oxygen partial pressure}

It is useful to compute the oxygen partial pressure, $\mathrm{pO}_{2}$, in equilibrium with a given state of the $\mathrm{Cu}-\mathrm{O}$ solution, since most of the measurements on changes in the surface energy of $\mathrm{Cu}$ as a result of $\mathrm{O}$-adsorption have been reported as a function of that variable.

The activity of $\mathrm{O}, \mathrm{a}_{\mathrm{O}}$, in the solution is evaluated from the known O-chemical potential (Eq. 8) as follows:

$$
\mu_{\mathrm{O}}-\mu_{\mathrm{O}}^{0}=\mathrm{RT} \ln \left(\mathrm{a}_{\mathrm{O}} / \mathrm{a}_{\mathrm{O}}^{0}\right)
$$

where $\mu_{0}^{0}$ and $a_{0}^{0}$ are the O-chemical potential and O-activity in the standard state, respectively. For convenience, the standard state is defined as the O-solution in equilibrium with $\mathrm{Cu}_{2} \mathrm{O}$, i.e. $\mu_{\mathrm{O}}^{0}$ is just $\mu_{\mathrm{O}}$ evaluated at $\mathrm{X}_{\mathrm{O}}^{\mathrm{C}}=0.02$ for a temperature of $1365 \mathrm{~K}$, and for which $\mathrm{a}_{\mathrm{O}}^{0}=1$ by definition. Since the $\mathrm{O}_{2}$ is diatomic in the gas phase, but dissolves in $\mathrm{Cu}$ as an atomic species:

$$
\mathrm{a}_{\mathrm{O}}=\left(\mathrm{pO}_{2} / \mathrm{pO}_{2}^{0}\right)^{1 / 2}
$$

where $\mathrm{pO}_{2}^{0}$ is the partial pressure of oxygen in the standard state, i.e. the partial pressure of oxygen in equilibrium with $\mathrm{Cu}_{2} \mathrm{O}$. Combining Eqs. 11 and 12:

$$
\mathrm{pO}_{2}=\mathrm{pO}_{2}^{0} \exp \left[\frac{2\left(\mu_{\mathrm{O}}-\mu_{\mathrm{O}}^{0}\right)}{\mathrm{RT}}\right]
$$

At $1365 \mathrm{~K}$ (the temperature at which evaluations are performed) $\mathrm{pO}_{2}^{0}=5 \times 10^{-6}$ atm [34].

\section{RESULTS AND DISCUSSION}


The equilibrium O-adsorption can be calculated by means of Eqs. 9. In Figs. 3 we show the effect on adsorption of changing the bond energies over the range $-23 \mathrm{~kJ} / \mathrm{mol}<$ $\varepsilon_{\mathrm{Cu}^{\prime} \mathrm{Cu}^{\prime}}<0 \mathrm{~kJ} / \mathrm{mol}$ at $1365 \mathrm{~K}$. Four examples are given for the bond energy choices listed in Table 2. Figures 3 are plots of the variation of the fractions of occupied $\mathrm{O} 1$ and $\mathrm{O} 2$-sites with increasing bulk oxygen concentration, extending all the way to the solubility limit. Figures $3 \mathrm{a}$ and $3 \mathrm{~b}$ display first order adsorption transitions, from a state of low adsorption to a state of high adsorption, as the bulk concentration of oxygen is increased. Such transitions have been predicted previously by segregation models in a number of different contexts $[13,35-37]$ and have been observed experimentally in solid metallic alloys [38-40]. The transitions do not occur for the bond energy choices of Figs. $3 \mathrm{c}$ and $3 \mathrm{~d}$. In addition, as the bond energies change from Fig. 3a to Fig. 3d, (i.e. to less negative values of $\varepsilon_{\mathrm{Cu}^{\prime} \mathrm{Cu}}$ ) they produce a reversal in the relative adsorptions in the two O-layers associated with the $\mathrm{Cu}^{(1)}$ plane. In Fig. 3a, adsorption is stronger in the O1-sites, whereas it is stronger in the $\mathrm{O} 2$-sites in Fig. 3b. It is worth noting that $\mathrm{O} 1$ and $\mathrm{O} 2$-sites have often been referred to in the literature as "on top" and "sub-surface" sites, respectively. In Figs. 3c and 3d, the continuing change to less negative $\varepsilon_{\mathrm{Cu}^{\prime} \mathrm{Cu}}$ progressively decreases the adsorption in the O1-sites, until it essentially vanishes in Fig. 3d, whereas the $\mathrm{O} 2$-sites continue to reach O-saturation, as the limit of O-solubility is approached.

It is also useful to consider the corresponding changes in surface energy that result from O-adsorption. The surface energy can be computed by means of Eq. 3, together with the expressions for adsorption and chemical potential of Eqs. 4 and 8, and the equilibrium values of $\mathrm{X}_{\mathrm{O} 1}$ and $\mathrm{X}_{\mathrm{O} 2}$ from Eqs. 9. The results are displayed in Fig. 4, as a plot of surface energy versus oxygen partial pressure, the latter being calculated by means of Eq. 13. The sets of bond energies used for illustration in Fig. 4 are identified in the legend, and correspond to those used in Fig. 3. The curves of Fig. 4 are also labeled "a" through "d" for reference to Figs. $3 \mathrm{a}$ to $3 \mathrm{~d}$.

As expected from the Gibbs adsorption isotherm, the slopes of the variation in surface energy with $\log \left(\mathrm{pO}_{2}\right)$ in Fig. 4 are proportional to the adsorption. In general, at low $\mathrm{pO}_{2}$ (or correspondingly low $\mathrm{X}_{\mathrm{O}}^{\mathrm{C}}$ in Fig. 3) the adsorption is negligible, and the slopes of the curves in Fig. 4 are essentially zero. As $\mathrm{pO}_{2}$ increases towards its maximum value at the limit of solubility, the slopes of the curves increase in absolute value. In cases such as those of Figs. $3 \mathrm{a}, 3 \mathrm{~b}$ and $3 \mathrm{~d}$, where $\mathrm{O}$-adsorption reaches a constant value at high $\mathrm{X}_{\mathrm{O}}^{\mathrm{C}}$, the slopes of the corresponding curves in Fig. 4 also approach a constant value at higher $\mathrm{pO}_{2}$, proportional to 
the maximum O-adsorption. Thus, the slopes of curves "a", and "b" in Fig. 4 reach a higher absolute value, corresponding to a maximum $\mathrm{O}$-adsorption where both $\mathrm{O} 1$ and $\mathrm{O} 2$-sites are fully occupied, whereas curve "d" reaches a slope about half as steep because the O2-sites are filled but the O1-sites remain vacant. Curve "c" of Fig. 4 displays an intermediate slope, as the O1-sites in that case are only partly occupied at the O-solubility limit.

One other issue is worth noting, for example in the case of curve "a" of Fig. 4. The first order adsorption transition that occurs in that case (Fig. 3a) produces a sharp break in slope in curve "a" which separates the low adsorption from the high adsorption regime.

We now proceed to a comparison of the predictions of the model with experimental data on the changes in surface energy of liquid $\mathrm{Cu}$ associated with O-adsorption. All of the data obtained at temperatures between 1365 and $1375 \mathrm{~K}$ [20-23] are summarized in Fig. 5. The best fit to the data occurs for curve "d" of Fig. 4, corresponding to the fourth set of bond energies displayed in Table $2\left(\varepsilon_{\mathrm{Cu}^{\prime} \mathrm{Cu}^{\prime}}=-5 \mathrm{~kJ} / \mathrm{mol}\right)$. It should be mentioned here that the value of the surface energy of pure liquid $\mathrm{Cu}$ used in the determination of model bond energies was obtained by averaging all of the experimental measurements displayed in Fig. 5 over the range $10^{-22}<\mathrm{pO}_{2}<10^{-14} \mathrm{~atm}$. One important conclusion that emerges from the good fit with experiment of the slope predicted by the model at relatively high $\mathrm{pO}_{2}$, is that the maximum experimental O-adsorption also corresponds to filling only half of the O-adsorption sites, specifically all of the $\mathrm{O} 2$ sites. By applying the Gibbs adsorption isotherm to the maximum (negative) slope predicted by the model in Fig. 5, it is possible to compute an O-adsorption of $\sim 7.1 \times 10^{-6}$ moles $/ \mathrm{m}^{2}$. This corresponds to about one adsorbed O-atom per four $\mathrm{Cu}$ surface atoms, consistent with filling all of the O2-adsorption sites. However, the experimental results do not provide any information on whether the upper or lower oxygen sites are occupied. Some insights into this issue may be gained by considering other modeling results.

As mentioned in the introduction, there has been significant activity using first principles methods that has focused on the interaction of oxygen with $\mathrm{Cu}$ surfaces. That work has addressed oxygen adsorption on various surface orientations of solid $\mathrm{Cu}$, and may not reflect the behavior of oxygen at the surface of liquid $\mathrm{Cu}$. Nevertheless, some of the issues studied may provide indications of trends, especially the work performed on the solid $\mathrm{Cu}(111)$ surface.

Calculations by Soon et al. [4] have investigated the relative stability of various Oadsorption sites on $\mathrm{Cu}(111)$. At low oxygen coverage, they find that the most stable site is the "on-top" site, which corresponds to our O1-site, whereas at higher coverage the on-top and 
subsurface site (our O2-site) become comparable in stability. However, at solid $\mathrm{Cu}$ surfaces, there are elastic strain energy effects that are absent in adsorption at the liquid surface. For example, in discussing O-adsorption at $\mathrm{Ag}(111)$ surfaces, $\mathrm{Li}$ et al. [41] point out that the lower stability of sub-surface sites is due primarily to distortion of the Ag lattice. The results we have shown in Fig. 3 clearly indicate that the relative stability of O1 and O2-sites depends on the choice of bond energies, and that some sets of bond energies favor O1-sites, while others favor O2-sites, as can be seen for example by comparison of Figs. $3 \mathrm{a}$ and $3 \mathrm{~d}$.

Another issue addressed by previous calculations is the possible formation of 2-d oxide layers for values of $\mathrm{pO}_{2}$ below those where bulk $\mathrm{Cu}_{2} \mathrm{O}$ is stable. $\mathrm{For} \mathrm{Cu}(111)$, Soon et al. [4] have found that as the O-chemical potential is increased there is essentially no Oadsorption at the $\mathrm{Cu}$ surface prior to formation of a sequence of 2-d oxides (each having a somewhat different $\mathrm{p} 4$-type structure). This situation is not very different from that displayed in Fig. 3b, where the fraction of occupied $\mathrm{O} 1+\mathrm{O} 2$-sites on the low side of the adsorption transition is only about $5 \%$, and where the state of the system on the high side of the adsorption transition amounts essentially to a 2-d oxide of composition $\mathrm{Cu}_{2} \mathrm{O}$.

Finally, it should be noted that sufficient data to define all of the model parameters (bond energies) are unavailable, thereby leading to one adjustable parameter. As a result, the model cannot currently be used in a completely predictive manner. Nevertheless, by fitting the model to the measured $\mathrm{pO}_{2}$ dependence surface energy of liquid $\mathrm{Cu}$, one can conclude that $\mathrm{O}$-adsorption to $\mathrm{Cu}$ surface is likely to be confined to O2-type, i.e. sub-surface, sites. Furthermore, the predictions of the model over the range of adjustable parameters seems to be consistent with several possible configurations of adsorbed oxygen that have been predicted by first principles calculations.

\section{CONCLUSIONS}

A model of $\mathrm{O}$-adsorption to the liquid $\mathrm{Cu}$ surface has been constructed. This differs from previous models of O-adsorption, in that it specifies adsorption sites in a realistic manner. The model contains one adjustable parameter. As this parameter is varied, it produces a variety of possible adsorption characteristics, including the possibility of first order transitions which lead to the formation of 2-d surface oxide layers, and different sequences for the occupancy of adsorption sites.

Fitting the model to the experimental variation of the surface energy of liquid $\mathrm{Cu}$ with O-partial pressure fixes the adjustable parameter. The adsorption behavior that corresponds to 
this choice of parameters, indicates that $\mathrm{O}$-adsorption to the surface of liquid $\mathrm{Cu}$ most likely occurs in sub-surface sites.

Acknowledgments. SC and DC wish to thank the European Commission $7^{\text {th }}$ Framework Program for facilitating the work reported in this publication, under contract FP7NMPA2009CSA-233484 MACAN, and PW wishes to acknowledge with thanks support of his research by the MRSEC Program of the National Science Foundation under Award No. DMR-0520425

\section{$\underline{\text { References }}$}

[1] F. Jensen, F. Besenbacher, E. Laegsgaard, I. Stensgaard, Surf. Sci. 259 (1991) L774.

[2] T. Matsumoto, R.A. Bennett, P. Stone, T. Yamada, K. Domen, M. Bowker, Surf. Sci. 471 (2001) 225.

[3] S.M. Johnston, A. Mulligan, V. Dhanak, M. Kadodwala, Surf. Sci. 519 (2002) 57.

[4] A. Soon, M. Todorova, B. Delley, C. Stampfl, Phys. Rev. B 73 (2006) 165424.

[5] P. Wynblatt, Annu. Rev. Mater. Res. 38 (2008) 173.

[6] E. Saiz, R.M. Cannon, A.P. Tomsia, Annu. Rev. Mater. Res. 38 (2008) 197.

[7] M.S. Daw, S.M. Foiles, M.I. Baskes, Mater. Sci. Rep. 9 (1993) 251.

[8] A. Landa, P. Wynblatt, A. Girshick, V. Vitek, A. Ruban, H. Skriver, Acta Mater. 46 (1998) 3027.

[9] B.C. Han, A. Van der Ven, G. Ceder, B.J. Hwang, Phys. Rev. B 72 (2005) 205409.

[10] D. McLean, Grain Boundaries in Metals. London: Oxford Press, 1957, p. 116.

[11] R. Defay, I. Prigogine, A. Bellmans, D.H. Everett, Surface Tension and Adsorption. New York (NY), Wiley, 1966, p. 158.

[12] P. Wynblatt, D. Chatain, Metall. and Mater. Trans. A 37 (2006) 2595.

[13] P. Wynblatt, A. Saul, D. Chatain, Acta Mater. 46 (1998) 2337.

[14] P. Wynblatt, R.C. Ku, Surface segregation in alloys. in: W.C. Johnson, J.M. Blakely editors. Interfacial Segregation. Metals Park (OH), ASM, 1979, p. 115.

[15] C. Antion, D. Chatain, Surf. Sci. 601 (2007) 2232.

[16] S. Iarlori, P. Carnevali, F. Ercolessi, E. Tosatti, Surf. Sci. 211 (1989) 55.

[17] F. Celestini, F. Ercolessi, E. Tosatti, Phys. Rev. Lett. 78 (1997) 3153.

[18] B.C. Lu, R.A. Rice, J. Chem. Phys. 68 (1978) 5558.

[19] O.M. Magnussen, M.J. Regan, E.H. Kawamoto, B.M. Ocko, P.S. Pershan, N. Maskil, M. Deutsch, S. Lee, K. Penanen, L.E. Berman, Physica B 221 (1996) 257. 
[20] B. Gallois, C.H.P. Lupis, Metall. Trans. B 12 (1981) 549.

[21] V. Ghetta, J. Fouletier, D. Chatain, Acta Mater. 44 (1996) 1927.

[22] S.P. Mehotra, A.C.D. Chaklader, Metall. Trans. B 16 (1985) 567.

[23] P.D. Ownby, J. Liu, J. Adhesion Sci. Technol. 2 (1988) 255.

[24] E. Ricci, A. Passerone, J.C. Joud, Surf. Sci. 206 (1988) 533.

[25] N. Eustathopoulos, B. Drevet, M.L. Muolo, Mater. Sci. Eng. A300 (2001) 34.

[26] C. Wagner, Acta Metall. 21 (1973) 1297.

[27] T. Chiang, Y.A. Chang, Metall. Trans. B 7 (1976) 453.

[28] Y.A. Chang, D.C. Hu, Metall. Trans. B 10 (1979) 43.

[29] M.L. Saboungi, P. Cerisier, M. Blander, Metall. Trans. B 13 (1982) 429.

[30] G. Belton, Metall. Trans. B 7 (1976) 35.

[31] T.E. Faber, Introduction to the Theory of Liquid Metals, Cambridge (UK), University Press, 1972.

[32] J.D.H. Donnay, Crystal Data Determinative Tables, 2nd edition. Washington (DC), American Crystallographic Association, 1963.

[33] S.Y. Sun, L. Zhang, S. Jahanshahi, Metall. Mater. Trans. B 34 (2003) 517.

[34] B. Hallstedt, D. Risold, L.J. Gaukler, J. Phase Equilibria 15 (1994) 483.

[35] C.R. Helms, Surf. Sci. 69 (1977) 689.

[36] P. Wynblatt, Y. Liu, J. Vac. Sci. Technol. A10 (1992) 2709.

[37] W-C. Cheng, P. Wynblatt, Surf. Sci. 364 (1996) 409.

[38] J. Eugene, B. Aufray, F. Cabane, Surf. Sci. 241 (1991) 84.

[39] Y. Liu, P. Wynblatt, Surf. Sci. 290 (1993) 335.

[40] W-C. Cheng, P. Wynblatt, Surf. Sci. 303 (1994) 179.

[41] W.X. Li, C. Stampfl, M. Scheffler, Phys. Rev. B 67 (2003) 045408. 


\section{Appendix I}

We provide here an explanation of the first term of Eq. 3:

$$
3 \mathrm{X}_{\mathrm{O} 1} \varepsilon_{\mathrm{Cu} \mathrm{O}^{\prime}}+4 \mathrm{X}_{\mathrm{O} 2} \varepsilon_{\mathrm{Cu} \mathrm{O}^{\prime}}+3 \mathrm{X}_{\mathrm{O} 1} \mathrm{X}_{\mathrm{O} 2} \varepsilon_{\mathrm{OO}}+0.5 \mathrm{X}_{\mathrm{O} 1} \mathrm{X}_{\mathrm{Ob}} \varepsilon_{\mathrm{OO}}+2 \mathrm{X}_{\mathrm{O} 2} \mathrm{X}_{\mathrm{Ob}} \varepsilon_{\mathrm{OO}}
$$

With the help of Figs. 1 and 2, it can be seen that 3Cu'-O bonds are formed for each occupied O1-site, accounting for an energy of $3 \mathrm{X}_{\mathrm{O} 1} \varepsilon_{\mathrm{Cu}^{\prime} \mathrm{O}}$; for each occupied $\mathrm{O} 2$-site $4 \mathrm{Cu}$-O bonds are formed, which amount to an energy of $4 \mathrm{X}_{\mathrm{O} 2} \varepsilon_{\mathrm{Cu}} \mathrm{O}$; each occupied $\mathrm{O} 2$-site also makes 3 bonds with the upper O-atoms, $\mathrm{O} 1$ (the energy is thus $3 \mathrm{X}_{\mathrm{O} 1} \mathrm{X}_{\mathrm{O} 2} \varepsilon_{\mathrm{OO}}$ ); each occupied O1-site is also connected to a lower O-site of $\mathrm{Cu}^{(2)}$ with an occupancy probability of $\mathrm{X}_{\mathrm{Ob}}$, for an energy of $0.5 \mathrm{X}_{\mathrm{O} 1} \mathrm{X}_{\mathrm{Ob}} \varepsilon_{\mathrm{OO}}$ (here the factor of 0.5 corrects for double counting when that bond is counted again from the second site); finally the term $2 \mathrm{X}_{\mathrm{O} 2} \mathrm{X}_{\mathrm{Ob}} \varepsilon_{\mathrm{OO}}$ accounts for $\mathrm{O}-\mathrm{O}$ interactions of an occupied $\mathrm{O} 2$-site with its 4 remaining O-neighbors (divided by two for double counting).

\section{$\underline{\text { Appendix II }}$}

The chemical potential of component B in a binary A-B solution may be expressed in terms of the molar free energy of the solution $\left(\mathrm{F}_{\mathrm{m}}\right)$ as:

$$
\mu_{B}=F_{m}+\left(1-X_{B}\right) d F_{m} / d X_{B}
$$

In the case of interest here, this may be rewritten as:

$$
\mu_{0}=F_{m}+\left(1-X_{0}^{c}\right) d F_{m} / d X_{0}^{c}
$$

To evaluate this expression, we transform the quantities defined in terms of $X_{0}^{C}$ into ones defined as functions of $\mathrm{X}_{\mathrm{Ob}}$, using the relationships of Eqs. 5 and 7. Together with the chain rule, this yields:

$$
\mu_{\mathrm{O}}=\frac{\mathrm{F}^{\mathrm{b}}\left(\mathrm{X}_{\mathrm{Ob}}\right)}{2 \mathrm{~N}_{\mathrm{O}}\left(2+\mathrm{X}_{\mathrm{Ob}}\right)}+\frac{2}{\left(2+\mathrm{X}_{\mathrm{Ob}}\right)} \frac{\mathrm{d}}{\mathrm{d} \mathrm{X}_{\mathrm{Ob}}}\left(\frac{\mathrm{F}^{\mathrm{b}}\left(\mathrm{X}_{\mathrm{Ob}}\right)}{2 \mathrm{~N}_{\mathrm{O}}\left(2+\mathrm{X}_{\mathrm{Ob}}\right)}\right) \frac{\mathrm{d} \mathrm{X}_{\mathrm{Ob}}}{\mathrm{dX_{O } ^ { \mathrm { C } }}}
$$

which simplifies to:

$$
\begin{aligned}
\mu_{\mathrm{O}} & =\frac{1}{2 \mathrm{~N}_{\mathrm{O}}} \frac{\mathrm{dF}^{\mathrm{b}}\left(\mathrm{X}_{\mathrm{Ob}}\right)}{\mathrm{d} \mathrm{X}_{\mathrm{Ob}}} \\
& =\left[8 \mathrm{X}_{\mathrm{Ob}} \varepsilon_{\mathrm{OO}}+4 \varepsilon_{\mathrm{Cu}^{\prime} \mathrm{O}}\right]+12\left[\frac{\partial \mathrm{f}_{\mathrm{CuCu}}^{(\mathrm{b})}}{\partial \mathrm{X}_{\mathrm{Ob}}} \varepsilon_{\mathrm{CuCu}}+\frac{\partial \mathrm{f}_{\mathrm{Cu}}^{(\mathrm{b})}}{\partial \mathrm{X}_{\mathrm{Ob}}} \varepsilon_{\mathrm{Cu} u^{\prime} \mathrm{Cu}}+\frac{\partial \mathrm{f}_{\mathrm{Cu}^{\prime} \mathrm{Cu}^{\prime}}^{(\mathrm{b})}}{\partial \mathrm{X}_{\mathrm{Ob}}} \varepsilon_{\mathrm{Cu}^{\prime} \mathrm{Cu}^{\prime}}\right]+\mathrm{RT}\left[\ln \left(\mathrm{X}_{\mathrm{Ob}} /\left(1-\mathrm{X}_{\mathrm{Ob}}\right)\right)\right]
\end{aligned}
$$




\section{TABLES}

Table 1

Bond fractions for near-surface $\mathrm{Cu}$-planes, and for bulk $\mathrm{Cu}$-planes, in terms of the fractions of occupied O-sites

\begin{tabular}{|c|c|}
\hline $\begin{array}{l}\text { Bond } \\
\text { fractions }\end{array}$ & Values \\
\hline $\mathrm{f}^{(1)} \mathrm{CuCu}$ & $\begin{array}{l}1-0.5 \mathrm{X}_{\mathrm{Ob}}-1.25 \mathrm{X}_{\mathrm{O} 1}-1.25 \mathrm{X}_{\mathrm{O} 2}+0.25 \mathrm{X}_{\mathrm{O} 1}^{2}+0.25 \mathrm{X}_{\mathrm{O} 2}^{2}+0.5 \mathrm{X}_{\mathrm{Ob}} \mathrm{X}_{\mathrm{O} 1}+ \\
0.5 \mathrm{X}_{\mathrm{Ob}} \mathrm{X}_{\mathrm{O} 2}+1.5 \mathrm{X}_{\mathrm{O} 1} \mathrm{X}_{\mathrm{O} 2}-0.25 \mathrm{X}_{\mathrm{O} 2} \mathrm{X}_{\mathrm{O} 1}^{2}-0.25 \mathrm{X}_{\mathrm{O} 1} \mathrm{X}_{\mathrm{O} 2}^{2}-0.5 \mathrm{X}_{\mathrm{Ob}} \mathrm{X}_{\mathrm{O} 1} \mathrm{X}_{\mathrm{O} 2}\end{array}$ \\
\hline $\mathrm{f}^{(1)} \mathrm{Cu} \mathbf{C}^{\prime} \mathrm{u}$ & $\begin{array}{l}0.5 \mathrm{X}_{\mathrm{Ob}}+\mathrm{X}_{\mathrm{O} 1}+\mathrm{X}_{\mathrm{O} 2}-0.5 \mathrm{X}_{\mathrm{O} 1}{ }^{2}-0.5 \mathrm{X}_{\mathrm{O} 2}{ }^{2}-\mathrm{X}_{\mathrm{Ob}} \mathrm{X}_{\mathrm{O} 1}-\mathrm{X}_{\mathrm{Ob}} \mathrm{X}_{\mathrm{O} 2}-1.5 \mathrm{X}_{\mathrm{O} 1} \mathrm{X}_{\mathrm{O} 2}+ \\
0.5 \mathrm{X}_{\mathrm{O} 1} \mathrm{X}_{\mathrm{O} 2}{ }^{2}+0.5 \mathrm{X}_{\mathrm{O} 2} \mathrm{X}_{\mathrm{O} 1}{ }^{2}+\mathrm{X}_{\mathrm{Ob}} \mathrm{X}_{\mathrm{O} 1} \mathrm{X}_{\mathrm{O} 2}\end{array}$ \\
\hline $\mathrm{f}^{(1)} \mathrm{Cu}^{\prime} \mathrm{Cu}^{\prime}$ & $\begin{array}{l}0.25 \mathrm{X}_{\mathrm{O} 1}+0.25 \mathrm{X}_{\mathrm{O} 2}+0.25 \mathrm{X}_{\mathrm{O} 1}^{2}+0.25 \mathrm{X}_{\mathrm{O} 2}^{2}+0.5 \mathrm{X}_{\mathrm{Ob}} \mathrm{X}_{\mathrm{O} 1}+0.5 \mathrm{X}_{\mathrm{Ob}} \mathrm{X}_{\mathrm{O} 2}- \\
0.25 \mathrm{X}_{\mathrm{O} 1} \mathrm{X}_{\mathrm{O} 2}^{2}-0.25 \mathrm{X}_{\mathrm{O} 2} \mathrm{X}_{\mathrm{O} 1}^{2}-0.5 \mathrm{X}_{\mathrm{Ob}} \mathrm{X}_{\mathrm{O} 1} \mathrm{X}_{\mathrm{O} 2}\end{array}$ \\
\hline $\mathrm{f}^{(1-2)} \mathrm{CuCu}$ & $\begin{array}{l}1-1.75 \mathrm{X}_{\mathrm{Ob}}-0.75 \mathrm{X}_{\mathrm{O} 1}-0.75 \mathrm{X}_{\mathrm{O} 2}+1.25 \mathrm{X}_{\mathrm{Ob}} \mathrm{X}_{\mathrm{O} 1}+1.25 \mathrm{X}_{\mathrm{Ob}} \mathrm{X}_{\mathrm{O} 2}+ \\
0.75 \mathrm{X}_{\mathrm{O} 1} \mathrm{X}_{\mathrm{O} 2}-1.25 \mathrm{X}_{\mathrm{Ob}} \mathrm{X}_{\mathrm{O} 1} \mathrm{X}_{\mathrm{O} 2}\end{array}$ \\
\hline $\mathrm{f}^{(1-2)} \mathrm{Cu} \mathrm{Cu}$ & $\begin{array}{l}1.5 \mathrm{X}_{\mathrm{Ob}}+0.75 \mathrm{X}_{\mathrm{O} 1}-2.5 \mathrm{X}_{\mathrm{Ob}} \mathrm{X}_{\mathrm{O} 1}+0.5 \mathrm{X}_{\mathrm{O} 2}-2.25 \mathrm{X}_{\mathrm{Ob}} \mathrm{X}_{\mathrm{O} 2}-0.75 \mathrm{X}_{\mathrm{O} 1} \mathrm{X}_{\mathrm{O} 2}+ \\
2.5 \mathrm{X}_{\mathrm{Ob}} \mathrm{X}_{\mathrm{O} 1} \mathrm{X}_{\mathrm{O} 2}\end{array}$ \\
\hline $\mathrm{f}^{(1-2)} \mathrm{Cu}^{\prime} \mathrm{Cu}^{\prime}$ & $0.25 \mathrm{X}_{\mathrm{Ob}}+0.25 \mathrm{X}_{\mathrm{O} 2}+\mathrm{X}_{\mathrm{Ob}} \mathrm{X}_{\mathrm{O} 2}+1.25 \mathrm{X}_{\mathrm{Ob}} \mathrm{X}_{\mathrm{O} 1}-1.25 \mathrm{X}_{\mathrm{Ob}} \mathrm{X}_{\mathrm{O} 1} \mathrm{X}_{\mathrm{O} 2}$ \\
\hline $\mathrm{f}^{(2)} \mathrm{CuCu}$ & $1-2.75 \mathrm{X}_{\mathrm{Ob}}-0.5 \mathrm{X}_{\mathrm{O} 2}+1.25 \mathrm{X}_{\mathrm{Ob}} \mathrm{X}_{\mathrm{O} 2}$ \\
\hline $\mathrm{f}^{(2)} \mathrm{Cu} u^{\prime} \mathrm{u}$ & $2.25 \mathrm{X}_{\mathrm{Ob}}+0.5 \mathrm{X}_{\mathrm{O} 2}-0.5 \mathrm{X}_{\mathrm{Ob}}^{2}-2.25 \mathrm{X}_{\mathrm{Ob}} \mathrm{X}_{\mathrm{O} 2}$ \\
\hline $\mathrm{f}^{(2)} \mathrm{Cu}^{\prime} \mathrm{Cu}^{\prime}$ & $0.5 \mathrm{X}_{\mathrm{Ob}}+\mathrm{X}_{\mathrm{Ob}} \mathrm{X}_{\mathrm{O} 2}+0.5 \mathrm{X}_{\mathrm{Ob}}^{2}$ \\
\hline $\mathrm{f}^{(2-3)} \mathrm{CuCu}$ & $1-3.25 \mathrm{X}_{\mathrm{Ob}}-0.25 \mathrm{X}_{\mathrm{O} 2}+3.75 \mathrm{X}_{\mathrm{Ob}}^{2}+0.5 \mathrm{X}_{\mathrm{Ob}} \mathrm{X}_{\mathrm{O} 2}$ \\
\hline $\mathrm{f}^{(2-3)} \mathrm{Cu} u^{\prime} \mathrm{Cu}$ & $2.75 \mathrm{X}_{\mathrm{Ob}}+0.25 \mathrm{X}_{\mathrm{O} 2}-5.75 \mathrm{X}_{\mathrm{Ob}}^{2}-0.75 \mathrm{X}_{\mathrm{Ob}} \mathrm{X}_{\mathrm{O} 2}$ \\
\hline $\mathrm{f}^{(2-3)} \mathrm{Cu}^{\prime} \mathrm{Cu}^{\prime}$ & $0.5 \mathrm{X}_{\mathrm{Ob}}+2 \mathrm{X}_{\mathrm{Ob}}^{2}+0.25 \mathrm{X}_{\mathrm{Ob}} \mathrm{X}_{\mathrm{O} 2}$ \\
\hline $\mathrm{f}^{(b)} \mathrm{CuCu}$ & $1-3.5 \mathrm{X}_{\mathrm{Ob}}+4.5 \mathrm{X}_{\mathrm{Ob}}^{2}-2.5 \mathrm{X}_{\mathrm{Ob}}^{3}+0.5 \mathrm{X}_{\mathrm{Ob}}^{4}$ \\
\hline $\mathrm{f}^{(b)} \mathrm{Cu} u^{\prime} \mathrm{Cu}$ & $3 \mathrm{X}_{\mathrm{Ob}}-7 \mathrm{X}_{\mathrm{Ob}}^{2}+5 \mathrm{X}_{\mathrm{Ob}}^{3}-\mathrm{X}_{\mathrm{Ob}}^{4}$ \\
\hline $\mathrm{f}^{(\mathrm{b})} \mathrm{Cu}^{\prime} \mathrm{Cu}^{\prime}$ & $0.5 \mathrm{X}_{\mathrm{Ob}}+2.5 \mathrm{X}_{\mathrm{Ob}}^{2}-2.5 \mathrm{X}_{\mathrm{Ob}}^{3}+0.5 \mathrm{X}_{\mathrm{Ob}}^{4}$ \\
\hline
\end{tabular}




\section{Table 2}

Bond energies used in examples $(\mathrm{kJ} / \mathrm{mol})$

$\begin{array}{ccccc}\varepsilon_{\mathrm{Cu}^{\prime} \mathrm{Cu}} & \varepsilon_{\mathrm{Cu} \mathrm{Cu}} & \varepsilon_{\mathrm{Cu}} \mathrm{O} & \varepsilon_{\mathrm{OO}} & \varepsilon_{\mathrm{CuCu}} \\ -23 & -27 & -3 & 14 & -31 \\ -19 & -25 & -111 & 26 & -31 \\ -13 & -22 & -273 & 44 & -31 \\ -5 & -18 & -489 & 68 & -31\end{array}$




\section{$\underline{\text { FIGURES }}$}

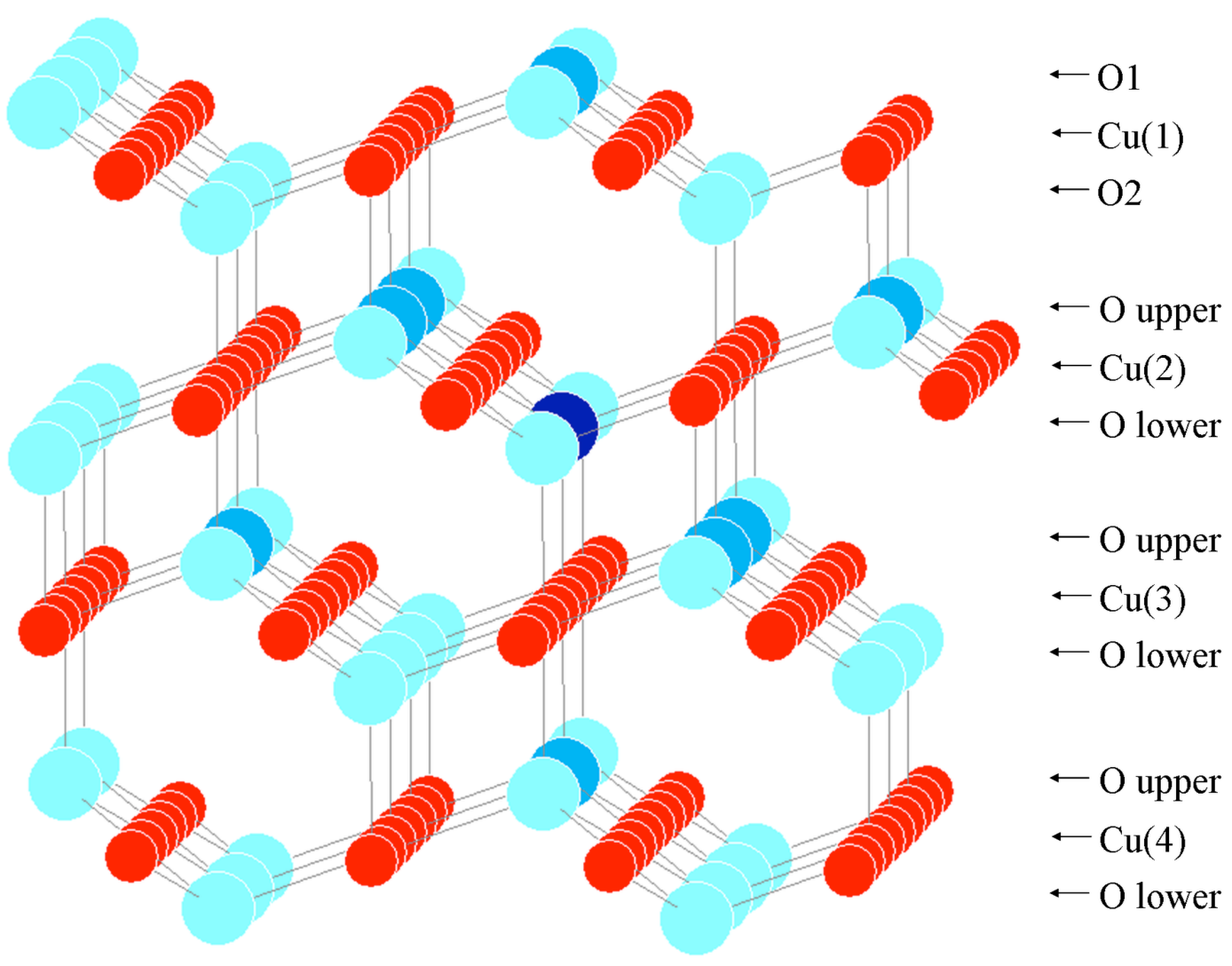

Figure 1. Crystal structure of $\mathrm{Cu}_{2} \mathrm{O}$. Small and large circles represent the $\mathrm{Cu}$ and $\mathrm{O}$ atoms, respectively. The first four near-surface copper planes, $\mathrm{Cu}^{(\mathrm{i})}$ (i=1 to 4), of a (111)-oriented surface are shown together with their associated $\mathrm{O}$ atoms. Only $\mathrm{O}-\mathrm{Cu}$ bonds are indicated. The black O-atom (blue on line) is used to illustrate the O-O coordination, by shading its Oneighbors in dark grey (medium blue on line). 


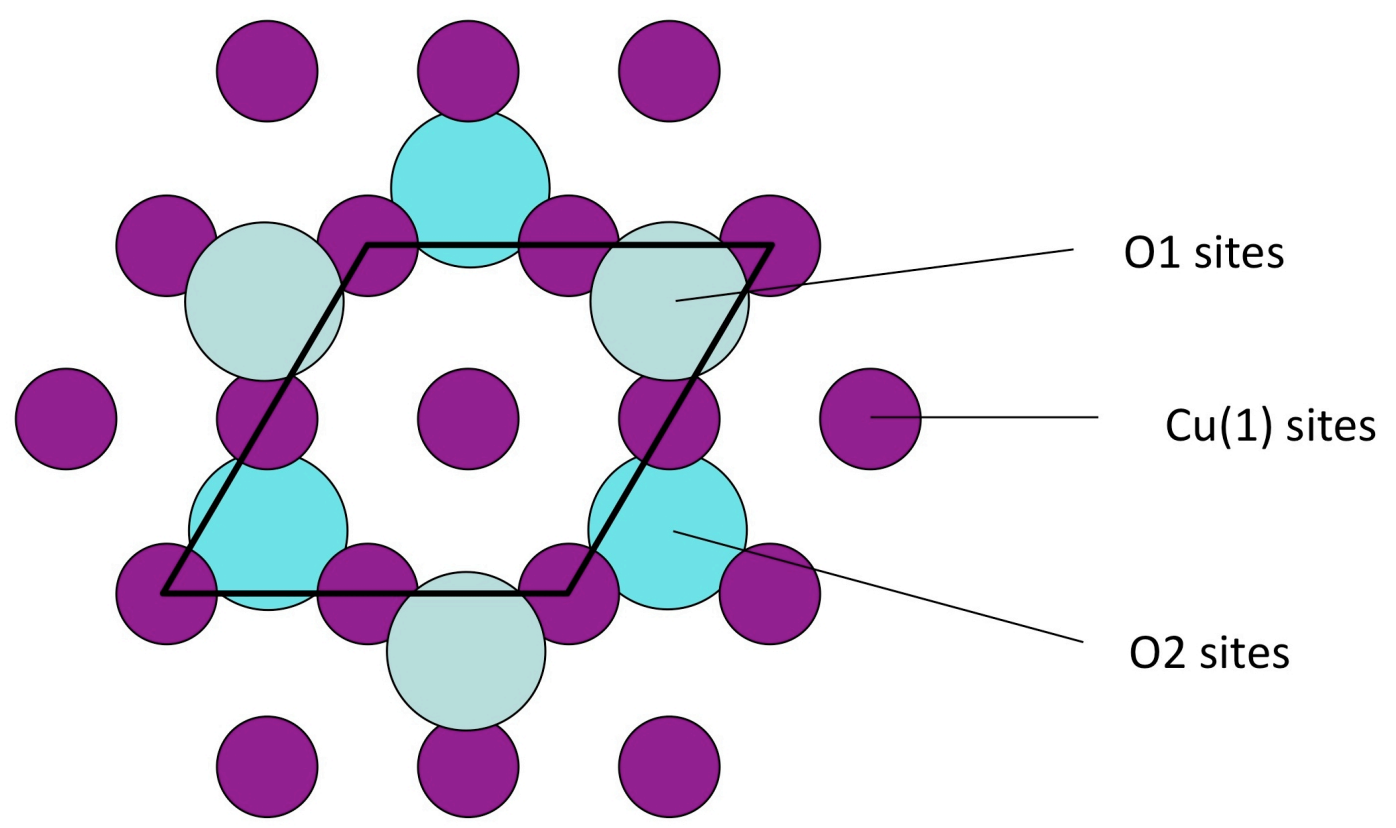

Figure 2. $\mathrm{Cu}_{2} \mathrm{O}$ structure viewed along [111] axis. Small and large circles represent the $\mathrm{Cu}$ and $\mathrm{O}$ atoms, respectively. The surface unit cell is indicated by the lozenge. 


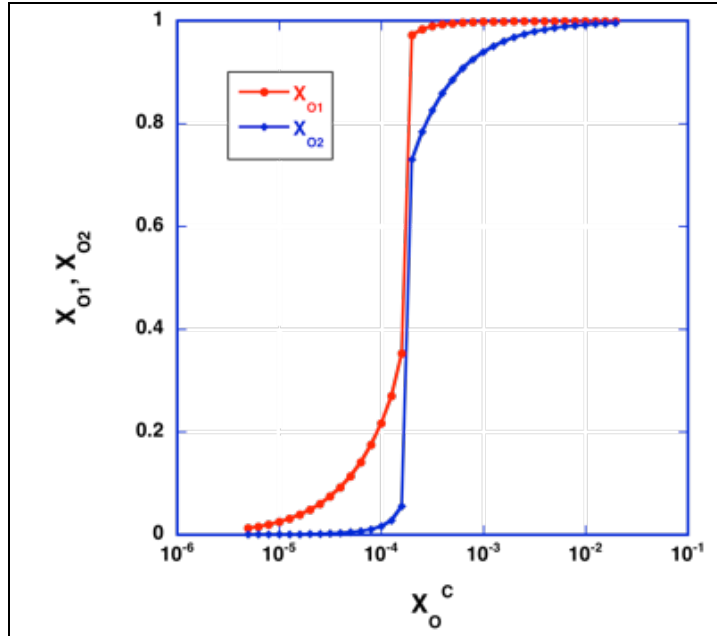

(a)

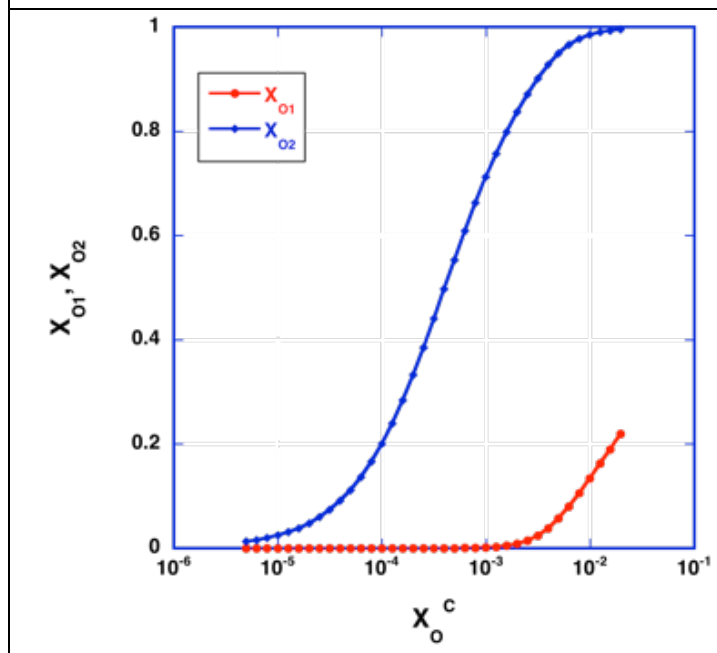

(c)

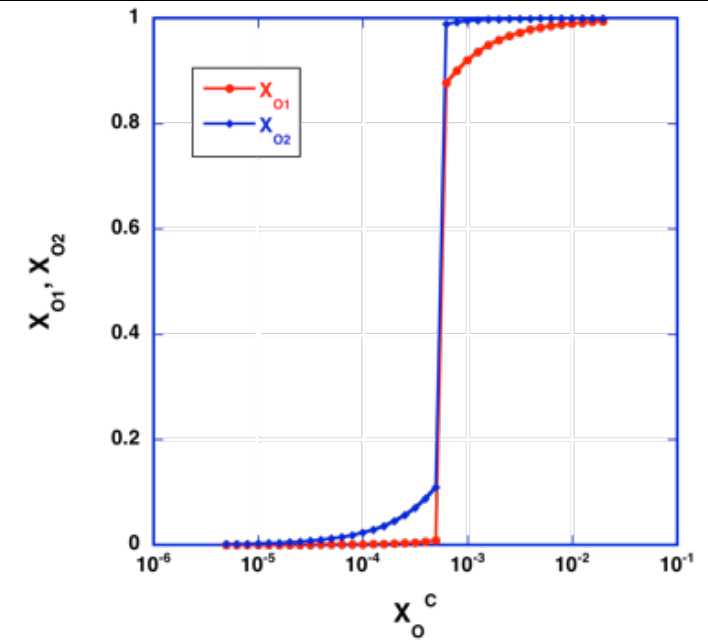

(b)

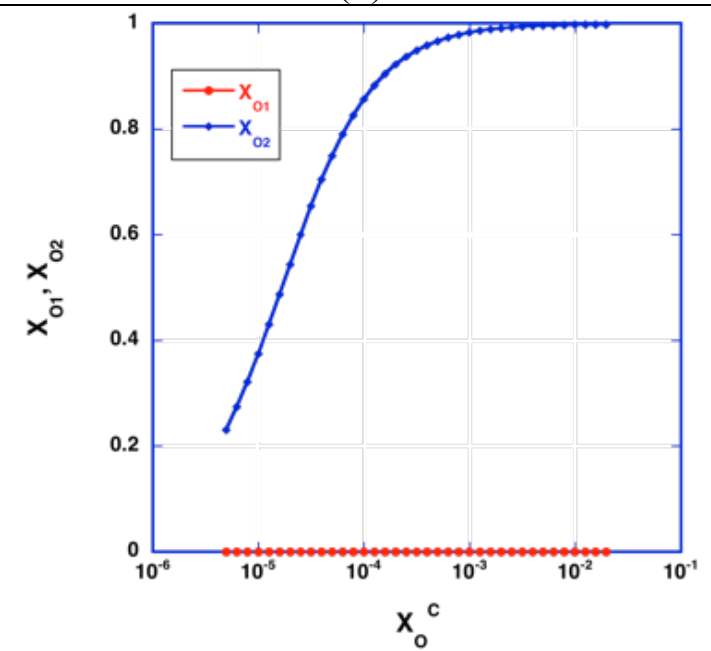

(d)

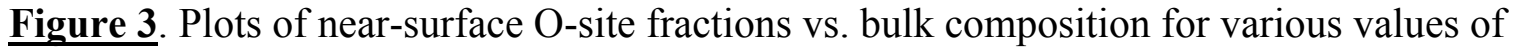
$\varepsilon_{\mathrm{Cu}^{\prime} \mathrm{Cu}^{\prime}}$ : (a) $-23 \mathrm{~kJ} / \mathrm{mol}$, (b) $-19 \mathrm{~kJ} / \mathrm{mol}$, (c) $-13 \mathrm{~kJ} / \mathrm{mol}$, (d) $-5 \mathrm{~kJ} / \mathrm{mol}$. 


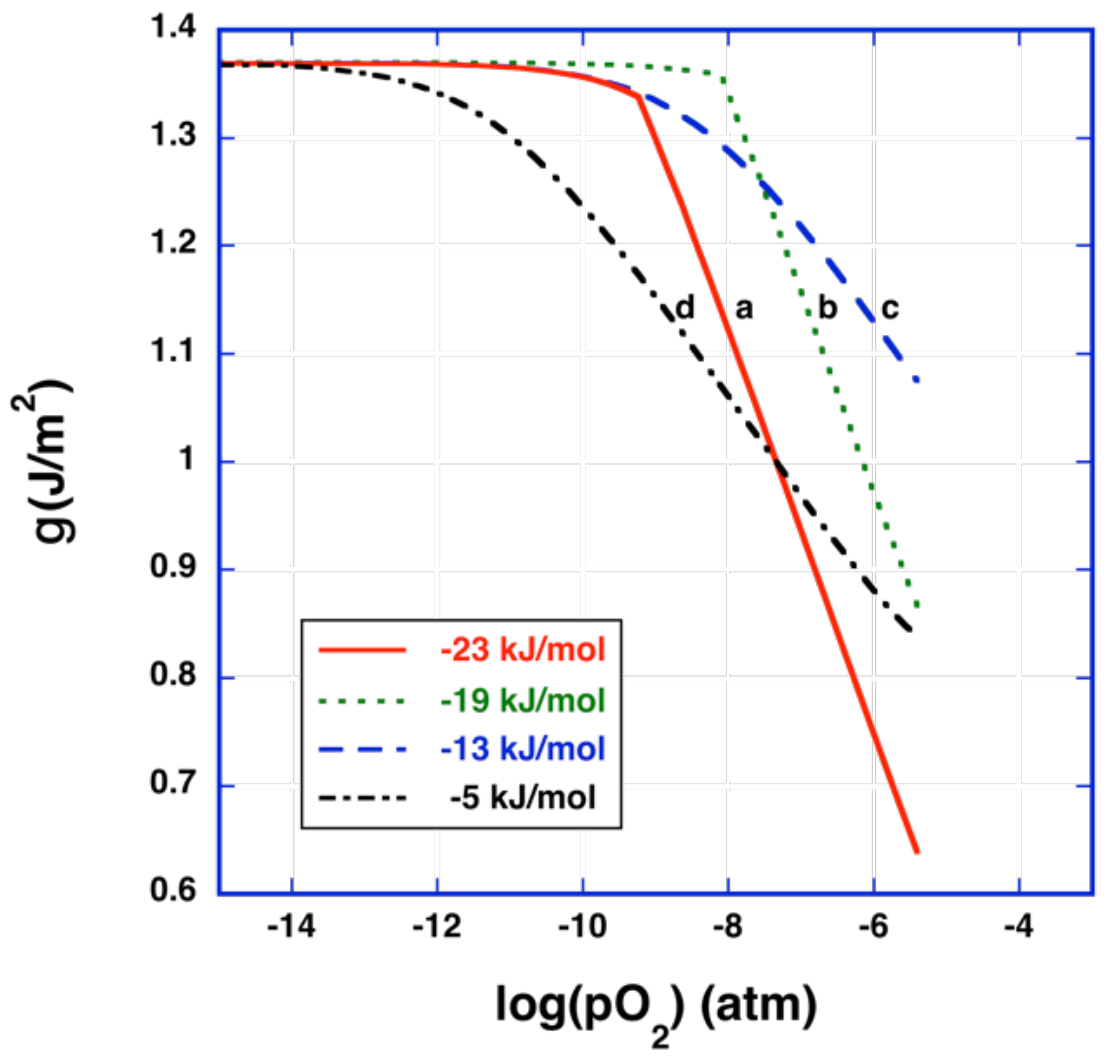

Figure 4. Plots of calculated surface energy vs. oxygen partial pressure for various values of $\varepsilon_{\mathrm{Cu}^{\prime} \mathrm{Cu}}$, as indicated in the legend. Curves are also labeled "a" to "d" for reference to Figs. $3 \mathrm{a}$ to $3 \mathrm{~d}$. 


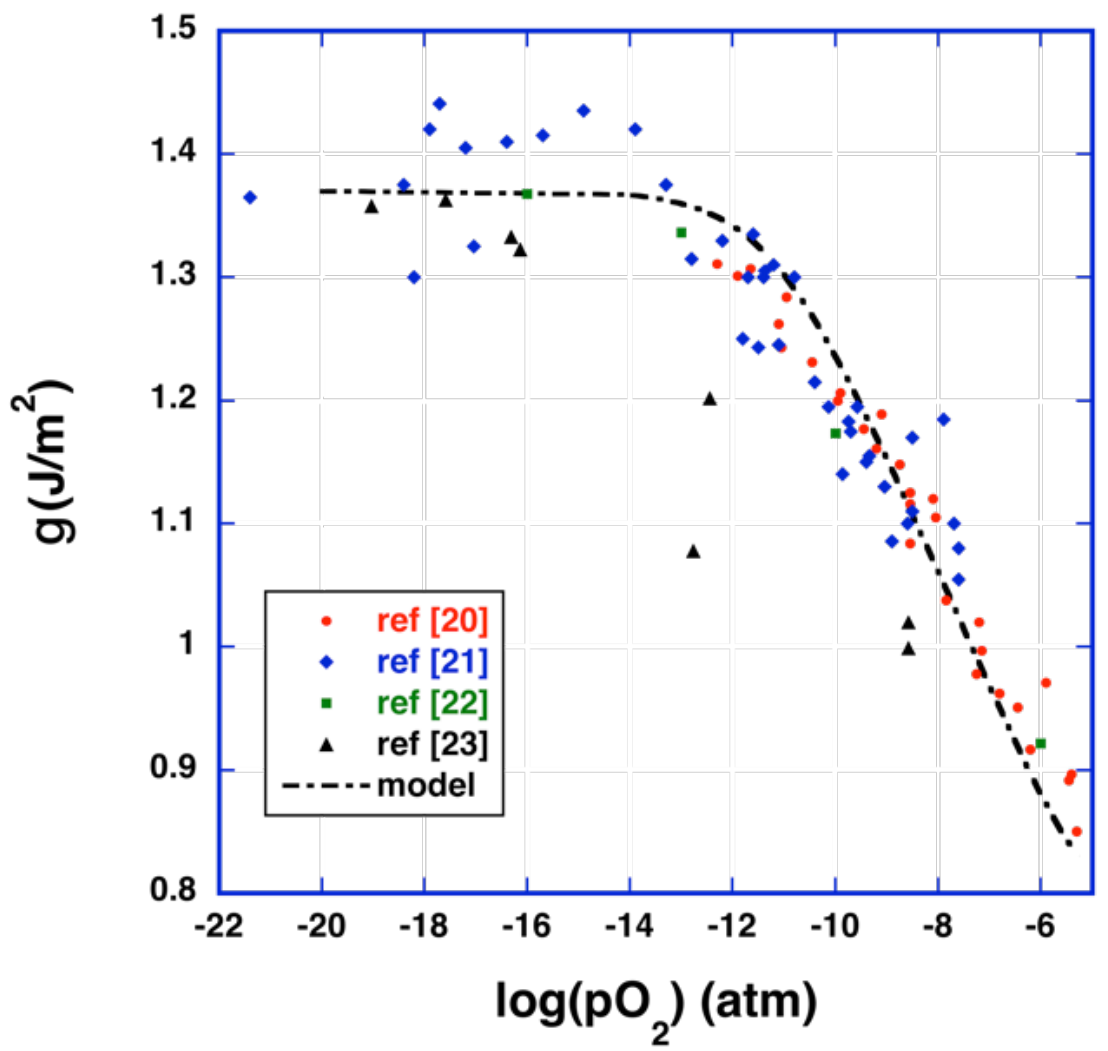

Figure 5. Surface energy of liquid $\mathrm{Cu}$ as a function of $\mathrm{O}$-partial pressure. Points represent measurements [20-23] and the line is the one labeled "d" in Fig. 4, corresponding to a bond energy choice of $\varepsilon_{\mathrm{Cu}^{\prime} \mathrm{Cu}^{\prime}}=-5 \mathrm{~kJ} / \mathrm{mol}$ in the model. 